\title{
LA OBTENCIÓN ILÍCITA DE LA FUENTE DE LA PRUEBA EN EL PROCESO CIVIL. ANÁLISIS COMPARATIVO DEL ORDENAMIENTO JURÍDICO ESPAÑOL Y CHILENO*
}

\author{
EDUARDO JEQUIER LEHUEDÉ $\hat{n}^{*}$
}

\begin{abstract}
RESUMEN: Este trabajo indaga sobre la fuente y los medios de prueba y la situación en materia de prueba ilícita en el derecho español, abarcando aspectos como la obtención directa e indirecta de la prueba ilícita, efectos procesales, análisis de jurisprudencia, doctrina del fruto del árbol prohibido. Como también desarrolla el tema en el derecho chileno, centrándose en la obtención de la prueba ilícita, su exclusión como prueba de fuente ilícita, sanción al ejercicio ilegítimo del derecho a la prueba, derechos fundamentales que pueden verse afectados por la actividad de obtención de prueba ilícita en la legislación nacional. En el mismo sentido trata además del reconocimiento explícito de que ha sido objeto la fuente ilícita en el actual código procesal penal chileno y de ausencia de norma expresa en el código de procedimiento civil.
\end{abstract}

Palabras claves: derecho procesal penal, medios de prueba, prueba ilícita, doctrina del fruto del árbol prohibido, prueba ilícita en la ley 19.968, prueba ilícita en el código de procedimiento civil.

ABSTRACT: This paper deals about the source and types of evidence, and the situation of illegal evidence in Spanish law, including aspects such as direct and indirect gathering of illegal evidence, procedural effects, jurisprudence analysis, fruit of the poisonous tree doctrine. The paper also describes the topic in Chilean law, focusing of the gathering and exclusion of illegal evidence, sanction to the illegal exercise of evidence law, fundamental rights that may be affected when gathering illegal evidence in national law. Finally, it discusses about the explicit treatment of illegal evidence in Chilean criminal procedural code, and the absence of specific norms in the civil procedure code.

Key words: Criminal procedure law, types of evidence, illegal evidence, tree poisoned fruit doctrine, illegal evidence in Law No 19.968, illegal evidence in code of civil procedure.

\section{INTRODUCCIÓN}

El presente trabajo de investigación comprende un análisis comparativo de las regulaciones normativas que presenta en la actualidad la figura de la obtención ilícita de la fuente de la prueba en el proceso civil, tanto en el ordenamiento jurídico español como en el chileno, y la evolución jurisprudencial que tal instituto procesal ha tenido en

\footnotetext{
* El presente trabajo fue realizado como parte del curso sobre "Proceso Civil: Principios, nuevas tecnologías y retos en la era de la globalización", dirigido por el Prof. Dr. Juan Montero Aroca y la Prof. Dra. Carolina Sanchis Crespo, en el marco del Programa de Doctorado "derecho, empresa y justicia" de la Universitat de Valencia (España), durante el primer semestre de 2007.

${ }^{* *}$ Profesor de Derecho Comercial y Derecho Económico de la Universidad Católica del Norte (Chile). Magíster en Derecho por la P. Universidad Católica de Chile. Abogado. Correo electrónico: ejequier@ucn. cl
} 
España desde su explícito reconocimiento por el Tribunal Constitucional de dicho país. Se trata, a mi parecer, de una materia de singular relevancia dogmática y trascendencia práctica, desde que en ella incardinan - por una parte- todo el sistema de derechos fundamentales que modelan la convivencia social en un Estado de Derecho, y -por la otra- el contenido y alcance del denominado "derecho a la prueba", con sus manifestaciones y consecuencias en el proceso civil en materia probatoria.

Para ello comenzaré por exponer algunos aspectos dogmáticos básicos que, sin embargo, son importantes de aclarar en punto a la prueba, sus fuentes y medios, para luego desentrañar el origen de la figura que nos ocupa en el derecho comparado y su ulterior implantación en el derecho español, como construcción jurisprudencial primero y con expreso reconocimiento legal después. A partir de ahí, se realizará una breve reseña de la jurisprudencia más relevante en España, para ocuparnos luego, en una segunda parte del trabajo, de analizar de manera sintética la situación actual de la legislación procesal chilena sobre la materia.

Debe aclararse, por último, que no es por simple casualidad ni obedece tampoco a un designio arbitrario el que se haya tomado como base de este análisis comparativo el modelado normativo y, en especial, el desarrollo jurisprudencial que en torno a esta institución se ha construido en el ordenamiento jurídico español. Antes por el contrario, y considerando precisamente la funcionalidad del Derecho comparado, dicho análisis se justifica muy especialmente aquí por cuanto, como se explicará más adelante, la experiencia española en este aspecto resulta especialmente ilustrativa en el marco del proceso por el que actualmente transita el Derecho chileno, orientado como sabemos a la necesaria revisión y actualización de la legislación procesal civil tal como ha ocurrido ya en otros ámbitos del ordenamiento nacional. Es en esta línea precisamente que se ha elaborado y ofrecido ya al debate interno un anteproyecto de Código Procesal Civil que, no obstante constituir por cierto una muy valiosa iniciativa de sus autores, incurre a mi entender en los mismos errores u omisiones que hace poco más de dos décadas cometió el legislador español al consagrar en términos genéricos este instituto de la prueba de fuente ilícita, sin incorporar simultáneamente sin embargo los vehículos procesales idóneos para hacerlo efectivo en juicio civil y concretar en él sus efectos. Esa omisión legislativa, como se verá igualmente, debió ser suplida y superada en el tiempo por una larga y muy significativa labor jurisprudencial del Tribunal Constitucional español, cuya doctrina derivó finalmente en una importante modificación a la Ley de Enjuiciamiento Civil del año 2000 que incorporó, precisamente, el indispensable escenario procesal a que recién me he referido.

En consecuencia, el presente trabajo no aspira más que a mostrar en último término la experiencia de un ordenamiento jurídico -el español- que, en este preciso aspecto de la prueba de fuente ilícita en el proceso civil, presenta sin duda rasgos de significativo avance en relación con los denominados sistemas continentales latinos y, por cierto, con el Derecho chileno en la misma materia. De lo que se trata, en fin, es de advertir simplemente sobre los riesgos de repetir los mismos errores y de evitar por lo mismo, en base a un entramado doctrinal y jurisprudencial que en Chile aun no se genera, sus innecesarias y predecibles consecuencias. 


\section{ALGUNAS CONSIDERACIONES SOBRE LA FUENTE Y LOS MEDIOS DE PRUEBA}

Como cuestión previa, resulta apropiado referirnos brevemente a dos conceptos que, aunque vinculados estrechamente entre sí, son sin embargo enteramente distintos: nos referimos, pues, a la fuente de la prueba por una parte y, por la otra, a los medios que la ley establece para allegarla al proceso.

Como señala Sentis ${ }^{1}$, la fuente de la prueba es un concepto metajurídico, extrajurídico o ajurídico, que corresponde a una realidad ajena al proceso y anterior al mismo. Por lo mismo, la fuente existirá aun cuando el proceso no llegue siquiera a existir, aunque en tal sentido carece de consecuencias jurídicas. El medio de prueba, en cambio, importa un concepto jurídico y puramente procesal, que nace junto y por el proceso. Según Carocca 2 , "el punto de partida de la actividad probatoria, es que las partes acuden al tribunal realizando afirmaciones de hecho, cuya prueba no podrá lograrse si no contando con algo que preexista al proceso, por ejemplo, un vecino que vio el hecho, una fotografía, una escritura pública, etc., que son las que constituyen lo que podemos denominar fuentes de prueba".

Según lo dicho y en una secuencia lógico-temporal entonces, lo primero será buscar la fuente de la prueba para luego incorporarla al proceso a través de los medios que la ley establece para ello. O dicho de otra forma: una cosa son las fuentes que existen antes del proceso y que, por lo mismo, no pueden enumerarse por la ley; y otra distinta la forma en que se llevan al proceso para formar el convencimiento del juez, por los medios que la ley enumera taxativamente.

Así por ejemplo, y como señala Montero ${ }^{3}$, en la prueba de testigos la fuente será el testigo mismo y el conocimiento que tiene de los hechos que se trate de establecer, y el medio su declaración en el juicio. En la prueba pericial, la fuente será la cosa, persona o materia objeto de la pericia, y el medio el informe y la actividad previa del perito para llevarlo a cabo. En la prueba confesional, asimismo, la fuente será la persona y el conocimiento que tiene de los hechos sobre los hechos, y el medio será la declaración que presta en el juicio a través de las posiciones que la plantea su contraparte. En el reconocimiento judicial, por último, la fuente será una cosa, lugar o persona, y el medio el examen personal y directo que de ellos hace el juez.

En consecuencia, y como aclara Sanchis ${ }^{4}$, "la búsqueda de fuentes por ser anteprocesal y extraprocesal, no está sujeta a garantías específicas y determinadas de orden procesal, sino a garantías de orden jurídico; las de orden procesal afectan totalmente a los medios o sea a la actividad a través de la cual las fuentes llegan al proceso".

\footnotetext{
1 Sentis Melendo (1978) pp. 151, 153 y 158; citado por SAnChis Crespo (1999) p. 68.

2 Carocca Pérez (S/D).

${ }^{3}$ Montero Aroca (1998) pp. 72 y 73, mencionado también por SANCHIS Crespo (1999) pág. 70.
} 


\section{LA OBTENCIÓN ILÍCITA DE LA FUENTE DE PRUEBA EN EL DERECHO ESPAÑOL}

\section{LA FIGURA EN EL DERECHO COMPARADO Y ESPAÑOL. CONSIDERACIONES GENERALES SOBRE SU ORIGEN Y DESARROLLO}

Aclaremos en primer término que en el Derecho español la ilicitud de la prueba hace referencia a la obtención de la fuente de la misma con infracción de derechos fundamentales, lo que importa por lo mismo -según comenzamos a analizar- su ineficacia y exclusión como tal en cuanto elemento de convicción en el proceso.

La ilicitud de la fuente de la prueba es, sin duda, una cuestión que se ha planteado con mucho mayor alcance en el proceso penal, lo que no significa sin embargo que no tenga repercusión en el proceso civil. Prueba de ello -esto es, que el proceso penal no monopoliza este tema- es que el primer pronunciamiento del Tribunal Constitucional español -TC- sobre esta cuestión fue en relación con un asunto incardinado en un proceso laboral y no penal, según veremos más adelante (STC 114/1984, de 29 de noviembre).

En cuanto a sus orígenes, la ineficacia de las pruebas obtenidas infringiendo derechos o libertades fundamentales tiene clara inspiración en la denominada exclusionary rule, aplicada en los Estados Unidos de América. Se trata de una regla jurisprudencial elaborada por la Corte Suprema de ese país, en virtud de la cual las fuentes de prueba (evidence) obtenidas por las fuerzas del orden público en el curso de una investigación criminal que violenten derechos y garantías procesales reconocidos en las Enmiendas Cuarta, Quinta, Sexta y Decimocuarta de la Constitución Federal, no podrán aportarse ni ser valoradas por el juez en la fase decisoria de los procesos penales federales o estatales, para determinar la culpabilidad o inocencia del acusado. Esta regla fue creada en 1914 en el caso Weeks v. United States ${ }^{5}$, de aplicación restringida a los Tribunales Federales, por lo que hubo que esperar a la resolución del caso Mapp. v. Ohio, 367, US, 643 (1961), fundado en la Decimocuarta Enmienda y en su cláusula del "due process of law", para que la exlusionary rule fuera extensiva a todos los Tribunales Estatales?.

Como señala Esparza ${ }^{8}$, esta regla de exclusión constituye para el Tribunal Supremo un importante remedio disuasorio frente a los abusos de la autoridad y, particularmente, de los agentes policiales en su labor de pesquisa, al punto que sus efectos abarcan tanto la prueba obtenida de manera directa como también la derivada o indirecta, como

\footnotetext{
${ }^{4}$ SANCHIS CRESPO (1999) pp. 68 y 69.

5 Weeks v. United States, 232 U. S. 383, 1914. Este fallo se considera como el precedente que da origen a la "exclusionary rule", aunque también pueden citarse los casos Rochin v. California (342 U. S. 165, 172, 1952, y Elkins v. United Status) 364 U. S. 206, 1960.

${ }^{6}$ Sobre esta cláusula puede consultarse la Tesis Doctoral de ESPARZA LEIBAR (1996).

${ }^{7}$ A su vez, el antecedente de la regla de exclusión comentada la encontramos en la jurisprudencia británica, en el caso Wilkes $v$. Word, de 1763, y Entick v. Carrington, de 1765. Al respecto, Fidalgo Gallardo (2003) pp. 88-94.

${ }^{8}$ Esparza Leibar (1996) p. 111.
} 
se dejó en claro en el caso Wong Sun v. United States 9 . Sin embargo, y considerando que la Cuarta Enmienda no se ocupa de la actividad de los particulares, la exclusión comentada no puede ser aplicada a aquellos casos en que la administración no ha participado en la obtención de las pruebas, aun cuando después haga uso de ellas ${ }^{10}$. Por otra parte, cabe agregar que la exclusión tampoco será aplicable a los casos de "descubrimiento inevitable" de la prueba, lo que ocurre cuando su obtención, aun cuanto resulte de una actividad ilegal de la policía, constituiría sin embargo una consecuencia necesaria e inevitable del procedimiento de investigación en cuanto tal ${ }^{11}$.

Por último, la regla solamente es aplicable al proceso penal, no siéndolo en cambio en los procesos civiles o administrativos de deportación, ni en procedimientos sancionatorios civiles en materia de impuestos ${ }^{12}$. Otro autor agrega también los casos de Juicios del Jurado y las vistas para la revocación de la libertad condicional ${ }^{13}$.

En España, por su parte, el primer reconocimiento legislativo sobre la obtención ilícita de la fuente de prueba y sus consecuencias en el proceso viene dado por el artículo 11.1 de la Ley Orgánica del Poder Judicial -LOPJ-, de 1985, en el que se contiene la regla general sobre esta materia al señalar:

"11.1. En todo tipo de procedimiento se respetarán las reglas de la buena fe. No surtirán efectos las pruebas obtenidas, directa o indirectamente, violentando los derechos o libertades fundamentales".

Advirtamos, con todo, que la redacción originaria de dicha norma en el Proyecto de Ley Orgánica del Poder Judicial ni siquiera mencionaba la figura legal que hoy en día está vigente. Así, el citado Proyecto de Ley proponía como redacción para el artículo 11 párrafo $1^{\circ}$ lo siguiente:

"El ejercicio de las acciones y la oposición, en todo tipo de procesos, respetará las reglas de la buena fe"lit.

Durante el trámite legislativo, sin embargo, el Grupo Parlamentario Popular decidió presentar una enmienda al texto original del artículo referido (en concreto la No 952), proponiendo para el mismo -en lo pertinente- la siguiente redacción:

\footnotetext{
9 Wong Sun v. United Status, 371 U. S. 471, 1963.

10 Esparza Leibar (1996) p. 112, fundado en el caso United Status v. Jacobsen, 466 U. S. 109, 1984.

11 Esparza Leibar (1996), citando el caso de Nix v. Williams, 467 U. S. 431, 1984.

12 Así se dijo para los procesos penales en United Status v. Calandra, 414 U. S. 338, 1974; para los procedimientos expropiatorios o confiscatorios en Plymouth Sedan v. Pennsylvania, 180 U. S. 693, 1965; para los procedimientos de deportación en I. N. S. v. López-Mendoza, 468 U. S., 1032, 1984; y para procesos sancionatorios civiles en materia de impuestos en United Status v. Manis, 428 U. S., 433, 1976.

13 FidALGO (2003) pp. 49-51.

14 Ley Orgánica del Poder Judicial (1986) p. 11.
} 
"No surtirán efecto, en ninguna clase de procesos, los medios de prueba obtenidos, directa o indirectamente, de modo contrario a la ética o al Derecho"15.

Esta enmienda, si bien no fue aprobada por la Comisión de Justicia, sí lo fue por el Pleno del Congreso de los Diputados, con lo cual se incorporó al Proyecto de LOPJ el texto recién transcrito. Posteriormente, por último, el Grupo Parlamentario Socialista en el Senado introdujo la enmienda No 374, proponiendo otra redacción al art. 11.1 LOPJ, diferente de la aprobada en la Cámara baja:

"No surtirán efecto las pruebas obtenidas, directa o indirectamente, violentando los derechos o libertades fundamentales".

Fue esta última la redacción definitiva que se dio al art. 11.1 LOPJ, al ser aprobada la enmienda antes mencionada y que se fundaba, concretamente, en que "...la referencia a las pruebas se acomoda a lo declarado por el Tribunal Constitucional en Sentencia dictada en el Recurso 114/84"16. Dicha sentencia, que se analizará más adelante, marcó sin duda un hito en el planteamiento y análisis constitucional del conflicto que genera la obtención de la fuente de la prueba con infracción de derechos fundamentales, pronunciándose explícitamente sobre la preeminencia que el ordenamiento jurídico le confiere al sistema de derechos fundamentales que estructura la convivencia social, por sobre la obtención a ultranza de la verdad formal que surge del proceso. Más aún, al tiempo de dictarse esta sentencia no existía en el derecho español ninguna fuente legal ni jurisprudencial que pudiese servir de antecedente para fundar el razonamiento contenido en la misma, lo que llevó al TC a recurrir incluso a fuentes extranjeras y a figuras como la exclusionary rule del Derecho estadounidense, ya mencionada ${ }^{17}$.

Tal fue la importancia de la STC 114/1984, por último, que su doctrina no solo sirvió de base para la redacción final del art. 11.1 LOPJ. Su influencia en el ordenamiento jurídico español, en efecto, se plasmó también en otras leyes que se han ocupado en el último tiempo de esta figura, entre las que se cuentan las siguientes:

\footnotetext{
${ }^{15}$ LEY ORGÁNiCA DEL PODER JUdicial (1986) pp. 527-528.

${ }^{16}$ En la justificación que realizó el Grupo Socialista hay que corregir un error, pues no se trataba del Recurso 114/84, sino de la Sentencia no 114/1984 que resolvía el recurso de amparo no 167/1984. LeY ORgÁNiCA DEL PODER JUdiCial (1986) vol. II, p. 1. 801.

17 F. J. 2 STC 114/1984 de 26 de noviembre: "En suma, puede traerse a colación la doctrina establecida por la Corte Suprema de los Estados Unidos respecto de la "evidence wrongfully obtained" y de la "exclusionary rule", en cuya virtud, en términos generales, no puede admitirse judicialmente el material probatorio obtenido con violación de la IV Enmienda a la Constitución. Así, en United States V. Janis (1976) la Corte declaró que “... la regla por la que se excluye la prueba obtenida en violación de la IV Enmienda tiende a garantizar los derechos generalmente reconocidos en dicha enmienda a través de un efecto disuasorio (de la violación misma) y no tanto como expresión de un derecho constitucional subjetivo de la parte agraviada...”.
} 
a) El art. 44 de la Ley 36/1988, de 5 de diciembre, de Arbitraje, señalaba que "los Jueces de Primera Instancia rechazarán fundadamente la práctica de pruebas contrarias a las leyes..."18

b) El art. 90. 1 del texto refundido de la Ley de Procedimiento Laboral, aprobado por Real Decreto Legislativo -RDL- 2/1995, de 7 de abril, dispone que "las partes podrán valerse de cuantos medios de prueba se encuentren regulados en la ley... salvo que se hubieran obtenido, directa o indirectamente, mediante procedimientos que supongan violación de derechos fundamentales o libertades públicas”.

c) El art. 36 de la Ley Orgánica 5/1995 del Tribunal del Jurado señala por su parte que “...al personarse las partes podrán...b) alegar la vulneración de algún derecho fundamental".

d) Por último, el art. 287 de la Ley de Enjuiciamiento Civil -LEC-1/2000, de 7 de enero, incorporó explícitamente y por vez primera al ordenamiento procesal civil español una completa regulación sobre la oportunidad y forma de alegar la ilicitud de la fuente de la prueba admitida en el juicio y, a partir de tal reclamación, su eventual exclusión como elemento de convicción en el mismo. Dada la relevancia de esta norma, hemos optado por tratarla a continuación y por separado.

\section{LA ILICITUD DE LA FUENTE DE LA PRUEBA EN EL ORDENAMIENTO PROCESAL ESPAÑOL}

\subsection{La ilicitud de la fuente de la prueba en la legislación procesal civil}

La nueva Ley de Enjuiciamiento Civil 1/2000 de 7 de enero, ha introducido en relación con esta cuestión, como hemos apuntado más arriba, una novedad importante respecto de la anterior Ley de Enjuiciamiento Civil de 1881: la regulación de la prueba ilícita en su art. 287, que pasamos a revisar.

\subsubsection{El artículo 287 de la LEC 1/2000, de 7 de enero:}

Como punto de partida de nuestro análisis en esta parte, conviene citar aquí el tenor del artículo 287 LEC, mencionado más arriba:

"287. Ilicitud de la prueba. - 1. Cuando alguna de las partes entendiera que en la obtención u origen de alguna prueba admitida se han vulnerado derechos fundamentales habrá de alegarlo de inmediato, con traslado, en su caso, a las demás partes.

Sobre esta cuestión, que también podrá ser suscitada de oficio por el tribunal, se resolverá en el acto del juicio o, si se tratase de juicios verbales, al comienzo de la vista, antes de que dé comienzo la práctica de la prueba. Al efecto, se oirá a las partes y, en su caso, se practicarán las pruebas pertinentes y útiles que se propongan en el acto sobre el concreto extremo de la referida ilicitud.

2. Contra la resolución a que se refiere el apartado anterior solo cabrá recurso de reposición, que se interpondrá, sustanciará y resolverá en el mismo acto del juicio o

18 Esta ley fue derogada por la Ley 60/2003 de 23 de diciembre, sobre arbitraje. 
vista, quedando a salvo el derecho de las partes a reproducir la impugnación de la prueba ilícita en la apelación contra la sentencia definitiva".

Decimos que se trata de una novedad importante, en efecto, porque la LEC de 1881 no contenía ninguna reglamentación en este sentido. Así lo señaló expresamente por lo demás el Consejo General del Poder Judicial, en el informe que hizo respecto del Anteproyecto de Ley de la actual LEC, donde refiriéndose al art. 332 del citado Anteproyecto -hoy art. 287 LEC-, dijo:

"Merece un juicio favorable la incorporación de esta materia (la prueba de fuente ilícita) a la Ley de Enjuiciamiento Civil, acogiendo en el derecho positivo lo que hasta ahora había nacido como una construcción jurisprudencial (especialmente desde la STC 144/1984) y tenía reflejo en el art. 11 LOPJ”19 (el paréntesis es nuestro).

Pero no solo constituye esta norma una novedad importante para la legislación procesal civil española, sino que también lo es a la luz del derecho comparado en esta materia. En efecto:

a) En Estados Unidos, según ya se dijo, no existe ninguna norma de tal calibre, por lo que son los propios tribunales los que aplican la doctrina de la exlusionary rule, explicada supra, con las limitaciones ya apuntadas.

b) Entre los llamados sistemas continentales latinos (España, Francia, Portugal e Italia), solo en España existe regulación de la obtención ilícita de la fuente de prueba en el proceso civil. En Italia se hace lo mismo, pero solo respecto del proceso penal (art. 191 Codice di Procedura Italiano ${ }^{20}$. En Portugal es la propia Constitución la que prohíbe la práctica de prueba obtenida ilícitamente (art. 32. 6) ${ }^{21}$, y también lo hace el Código de Processo Penal en su art. 12622. Finalmente, en Francia no se ha legislado sobre esta

${ }^{19}$ Ley de Enjuiciamiento Civil y Reforma de la Ley Orgánica del Poder Judicial (1998) p. 165.

20 "Art. 191 (Prove illegittimamente acquisite):

1. Le prove acquisite in violazione dei divieti stabiliti dalla legge non possono essere utilizzate.

2. L'inutilizzabilità è rilevabile anche di ufficio in ogni stato e grado del procedimento".

21 "Art. 32. 6: Serán nulas todas las pruebas obtenidas mediante tortura, coacción, atentado a la integridad física o moral de la persona o intromisión abusiva en la vida privada, en el domicilio, en la correspondencia o en las telecomunicaciones".

22 "Artigo $126^{\circ}$ Métodos proibidos de prova:

1 - São nulas, não podendo ser utilizadas, as provas obtidas mediante tortura, coacção ou, em geral, ofensa da integridade física ou moral das pessoas.

2 - São ofensivas da integridade física ou moral das pessoas as provas obtidas, mesmo que com consentimento delas, mediante:

a) Perturbação da liberdade de vontade ou de decisão através de maus tratos, ofensas corporais, administração de meios de qualquer natureza, hipnose ou utilização de meios cruéis ou enganosos;

b) Perturbação, por qualquer meio, da capacidade de memória ou de avaliação;

c) Utilização da força, fora dos casos e dos limites permitidos pela lei;

d) Ameaça com medida legalmente inadmissível e, bem assim, com denegação ou condicionamento da obtenção de benefício legalmente previsto;

e) "Promessa de vantagem legalmente inadmissível". 
cuestión, siendo también la jurisprudencia la que ha establecido el camino para que no se practiquen en el proceso las pruebas cuya fuente ha sido adquirida de forma ilícita ${ }^{23}$.

\subsubsection{Alcance y ámbito de aplicación del artículo 287 LEC:}

Podría tal vez reprochársele al legislador el no haber precisado en el artículo 287 LEC qué debe entenderse por prueba ilícita, ni haberlo hecho respecto de los efectos concretos que esta produce en el proceso. Sin embargo, tal crítica no tendría mayor justificación por cuanto, junto con la norma citada, cobra plena aplicación la norma general del artículo 11.1 LOPJ, que claramente se refiere a la infracción de derechos fundamentales y al resultado de exclusión absoluta de la prueba obtenida por esa vía.

En punto al primer aspecto -infracción de derechos fundamentales-, debemos aclarar además que en el art. 11.1 LOPJ solo se protegen los derechos y libertades fundamentales recogidos en la Constitución de 1978 y los Pactos y Convenios Internacionales sobre derechos humanos y libertades fundamentales suscritos por España (tal y como obliga el art. 10.2 CE), dejando de lado al resto de derechos subjetivos. En esta línea es precisamente en la que se sitúa el art. 287 LEC.

\subsubsection{Iniciativa en la obtención ilícita de la fuente:}

Por otra parte, y en lo que concierne a la iniciativa en la obtención ilícita de la fuente de prueba en el proceso civil, señalemos que esta puede provenir de la actividad particular, sin autorización judicial previa, o con tal autorización cuando se restringe o afecta un derecho fundamental. Veamos cada situación:

10) En primer término, podemos estar ante una actividad realizada por una de las partes de forma unilateral, vulnerando alguno de estos derechos o libertades. Puede ser el caso de un testigo que declare bajo la coacción de alguna de las partes o de los investigadores privados que obtengan informes que se presenten como prueba documental vulnerando derechos fundamentales, sobre todo en el marco del derecho a la intimidad del art. 18 de la CE (intervención de comunicaciones telefónicas, inviolabilidad del domicilio fundamentalmente).

2o) En el supuesto de que la actividad probatoria se realice dentro del proceso por el juez, para incorporar las fuentes de prueba al mismo, aquella nunca puede suponer violación de derechos fundamentales absolutos (véase derecho a la vida o a la integridad física) en tanto y en cuanto se realice al amparo de la ley. Hay que destacar, en efecto, que la LEC autoriza la restricción de algunos derechos fundamentales para la obtención de la fuente de prueba, las que en todo caso deben ser autorizadas por el juez. Así ocurre con (a) las entradas y registros domiciliarios reguladas en las reglas segunda, tercera y quinta del art. 261 en materia de diligencias preliminares; (b) la medida prevista en el art. 354 para poder practica el reconocimiento judicial, pudiendo ordenar la entrada en el lugar donde se deba realizar el reconocimiento; y, en fin, (c) con la declaración de algún testigo en su domicilio (art. 364), sin perjuicio del

${ }^{23}$ La precursora fue la Sentencia del Tribunal de Casación de 18 de marzo de 1955. 
derecho y deber de los testigos en general en orden a guardar el secreto profesional o religioso a que se refiere el art. 371.1.

Por otra parte, y como lo ha señalado el TC, en caso de conflicto de derechos en juego se deben conciliar unos con otros, tanto fundamentales como relativos y también con intereses sobresalientes. Ejemplo de ello sería el pronunciamiento que hallamos en la STC 95/1999, de 31 de mayo, donde se estima que en el curso de un pleito de filiación, llevar a cabo un reconocimiento hematológico como prueba pericial no puede considerarse degradante para la persona sujeta al mismo, ni contrario a su dignidad (F. J. $2)^{24}$. En este supuesto estamos ante un caso en el que se compatibiliza un derecho fundamental [derecho a la intimidad (art. 18. 1CE)] con un interés preferente.

\subsubsection{Fuente de la prueba obtenida con infracción de otros derechos reconocidos en la CE 1978}

Tratándose ahora de otro tipo de derechos, considerados no fundamentales por la CE 1978 (Capítulo II, Sección 2a, artículos 30 a 38), la fuente obtenida con infracción de los mismos podrá no obstante ser incorporada al proceso por el medio de prueba pertinente, sin posibilidad de impetrar su exclusión al amparo de los artículos 11.1 LOPJ y 287 LEC. Así entonces, la prueba obtenida con infracción de derechos tan relevantes como -v. gr.- el derecho a la propiedad privada regulado en el art. $33 \mathrm{CE}$ [a excepción de la inviolabilidad del domicilio, que sí es un derecho fundamental (art. 18. $2 \mathrm{CE}$ )], deberá ser admitida en el proceso por aplicación del derecho general a la prueba; sin perjuicio, por cierto, de las posibles responsabilidades en que pudiera incurrir el autor de la obtención de la fuente.

En este sentido, y si bien no hemos encontrado jurisprudencia en materia civil sobre la materia, existen sentencias penales cuya doctrina resulta perfectamente aplicable al proceso civil. Así por ejemplo, la STS de 29 de marzo de 1990, señala que "cuando el origen de la ilicitud de la prueba se encuentra en la violación de un derecho fundamental, no hay ninguna duda de que tal prueba carece de validez en el proceso... Otra cosa quizá haya que decir cuando la ilicitud sea de rango inferior, en cuyo supuesto es posible que tenga que prevalecer el principio de verdad material..." (Fundamento de Derecho $2^{\circ}$ ).

\footnotetext{
${ }^{24}$ F. J. 2 STC 95/1999 de 31 de mayo: "Este Tribunal ha declarado la plena conformidad constitucional de la resolución judicial que, en el curso de un pleito de filiación, ordena llevar a cabo un reconocimiento hematológico, pues este tipo de pruebas, que no pueden considerarse degradantes, ni contrarias a la dignidad de la persona, encuentran su cobertura legal en el art. 127 del Código Civil, que desarrollando el mandato contenido en el inciso final del art. 39. 2 CE, según el cual "La ley posibilitará la investigación de la paternidad", autoriza la investigación de la relación de paternidad o de maternidad en los juicios de filiación, mediante el empleo de toda clase de pruebas, incluidas las biológicas, a la vez que sirven para la consecución de la finalidad perseguida con las normas constitucionales que imponen "la protección integral de los hijos, iguales estos ante la ley con independencia de su filiación" (art. 39. 2 CE), y la obligación de los padres de "prestar asistencia de todo orden a los hijos habidos dentro o fuera del matrimonio" (art. 39. 3 CE). Por ello, cuando sean consideradas indispensables por la autoridad judicial, no entrañen un grave riesgo o quebranto para la salud de quien deba soportarlas, y su práctica resulte proporcionada, atendida la finalidad perseguida con su realización, no pueden considerarse contrarias a los derechos a la integridad física (art. 15 CE) y a la intimidad (art. 18. 1 CE) del afectado (STC 7/1994 fundamento jurídico 30)".
} 
En resumen, las fuentes de prueba obtenidas ilícitamente quebrantando derechos no fundamentales, tienen que ser aceptadas en el proceso y tratándose de derechos fundamentales, no deben producir efectos en el proceso las pruebas así adquiridas.

\subsubsection{Obtención indirecta de la prueba ilicita; los "frutos del árbol envenenado"}

Hasta ahora hemos tratado la obtención ilícita de la fuente de prueba de manera directa, pero los artículos 11.1 LOPJ y 287 LEC regulan también la obtención ilícita indirecta, recogiendo así la doctrina anglosajona conocida como "frutos del árbol envenenado" (fruit of the poisonous tree doctrine).

Se trata de una teoría recogida por primera vez en España en la STC 86/1995, de 6 de junio, y consiste - como señala Fidalgo ${ }^{25}$ - en que "si ha de evitarse todo efecto en el proceso de los materiales probatorios o informaciones que han sido obtenidos de modo irregular, igualmente deberá proscribirse la admisión de informaciones o materiales obtenidos gracias a la previa irregularidad acaecida".

Según esto entonces, la inadmisibilidad de la que venimos hablando abarca tanto las fuentes obtenidas directamente con infracción de un derecho fundamental, como indirectamente.

\subsubsection{Efectos procesales de la prueba de fuente ilícita}

Avanzado ya nuestro análisis sobre el origen y naturaleza jurídica del instituto que nos ocupa, cabe preguntarnos a estas alturas sobre cuáles van a ser los efectos procesales de una fuente obtenida ilícitamente, que se pretende incorporar al proceso por el medio de prueba oportuno.

Desde luego, el artículo 11.1 LOPJ no dice nada acerca del mecanismo que se debe emplear para que la obtención de una fuente de prueba sea declarada ilícita en juicio, limitándose a señalar que la prueba derivada de esta no surtirá efecto. Por lo anterior, en esta parte habrá que estarse exclusivamente a lo dispuesto por el art. 287 LEC, que señala que la alegación por la admisión en el proceso de alguna prueba obtenida con infracción de derechos fundamentales, corresponde únicamente a la parte afectada; sin perjuicio de la facultad que se le reconoce al juez para suscitar la cuestión de oficio. Según Montero ${ }^{26}$, además, “esta norma está partiendo de que el tribunal, en el momento de la admisión de los medios de prueba, carece de elementos de juicio para inadmitir uno de ellos por ilicitud en la obtención de la fuente", por lo que en la norma se hace especial hincapié en que la parte que considere infringidos determinados derechos fundamentales en la obtención de una prueba, debe alegarlo de inmediato en el juicio, con traslado a las demás partes.

Asimismo, para reclamar de la ilicitud el medio de prueba debe haber sido propuesto y admitido en el proceso (artículos 283 y 285 LEC), sin necesidad de interponer -por contradictorio- el recurso de reposición a que se refiere el artículo 285.2 LEC.

\footnotetext{
25 Fidalgo Gallardo (2003) pp. 35-36.

${ }^{26}$ Montero Aroca (2002) p. 143.
} 
La cuestión se resolverá en el acto del juicio en el caso del proceso ordinario, o al inicio de la vista si se tratase de juicios verbales, antes del comienzo de la práctica de prueba (artículos 433.1 y 446 LEC). Se oirán a las partes y, en su caso, se practicarán las pruebas pertinentes y útiles que se propongan en el acto sobre el concreto extremo de la ilicitud. La resolución será un auto (artículo 206.2.2a y art. 208.2 LEC), pero se hará de forma oral. Si el juez declara la ilicitud de la fuente, el medio de prueba no se practicará, y al contrario, si se declara lícita sí se ejercitará. En el supuesto de que la ilicitud en la obtención de la fuente se constatara una vez iniciada la práctica de prueba, lo que se deberá plantear será la nulidad de la prueba ilícita practicada (artículo 227.2 LEC y 240.2 LOPJ).

El auto se podrá impugnar mediante recurso de reposición, en el mismo acto del juicio o de la vista, lo cual implica que se efectúe en forma oral. Lo anterior, sin embargo, va en contra de lo establecido en los artículos 451 a 454 LEC, reguladores del recurso de reposición, "cuando lo procedente hubiera sido decir que contra la resolución oral queda únicamente la protesta a hacer constar en el acta" 27 (artículo 287.2 LEC). En los juicios verbales, no se interpone recurso de reposición, se deberá formular protesta (artículo 446 LEC).

La sentencia definitiva podrá ser recurrida en apelación (artículo 287.2 LEC). También cabe recurso de casación, según Gimeno ${ }^{28}$, "si se dan los supuestos previstos en el artículo 477 (LEC) y con base en el artículo 50 LOPJ, dado que la infracción de derechos fundamentales que ocasiona la ilicitud de una prueba nunca lo es con vulneración del art. $24 \mathrm{CE}$, sino de cada uno de los derechos afectados".

Una cuestión problemática que se plantea en esta parte consiste en determinar qué ocurre cuando el juez, en el momento de dictar sentencia, se percata de que la fuente de prueba se ha obtenido ilícitamente. La LEC no dice nada al respecto, con lo cual existe un vacío legal. Se podría interpretar que en tales casos el juez tendría igualmente facultades para cuestionar la licitud de la fuente de oficio, con apoyo en el artículo 287. 1, II LEC ("sobre esta cuestión, que también podrá ser suscitada de oficio por el tribunal...”). Aceptando esto, van a surgir sin embargo dos problemas:

a) Uno es el relativo a la indefensión y posible vulneración del artículo $24.2 \mathrm{CE}$, puesto que se infringe el principio de contradicción al permitirle al juez excluir de oficio una prueba admitida y practicada en el proceso, sin previa audiencia de la parte que la rindió (lo que importa incluso privarla de la oportunidad de demostrar la licitud en la adquisición de la fuente).

b) El segundo problema vendría dado porque a pesar de que la prueba ilícita no va a surtir efectos, el juez la ha conocido e inconscientemente puede formar en ella su convicción ${ }^{29}$.

\footnotetext{
${ }^{27}$ Montero Aroca (2002) p. 144.

${ }^{28}$ GIMENO SENDRA (2005) p. 143

${ }^{29}$ Montero Aroca (2002) p. 144.
} 


\section{ANÁlisis de LA JURISPRUDENCIA Y EN ESPECIAL LA DEL TRIBUNAL} CONSTITUCIONAL ESPAÑOL

En este apartado vamos a comentar una selección jurisprudencial sobre obtención ilícita de la fuente de prueba dada por el Tribunal Constitucional, así como la doctrina de los frutos del árbol envenenado.

Respecto del primer aspecto, y por su indudable relevancia, se analizará con más detalle la STC 114/1984 de 26 de noviembre. En lo que concierne al segundo, y por la misma razón apuntada, nos detendremos en la STC 81/1998 de 2 de abril.

\subsection{Obtención ilícita de la fuente de prueba; STC 114/1984 de 26 de noviembre}

Ya hemos advertido que la mayoría de los pronunciamientos sobre esta materia se refieren al ámbito del proceso penal. Sin embargo, en los supuestos de infracción de los derechos a la intimidad y al honor, tales como el secreto de las comunicaciones o la inviolabilidad del domicilio, la doctrina dada en esta sentencia por el Tribunal Constitucional es perfectamente extrapolable al proceso civil.

\section{a) Resumen de antecedentes de hecho}

Se trata de un recurso de amparo interpuesto contra la Sentencia de la Magistratura de Trabajo núm. 4 de Alicante, de 10 de mayo de 1983, que declaró procedente el despido del actor, así como contra la Sentencia dictada en recurso de casación por la Sala Sexta del Tribunal Supremo con fecha de 15 de febrero de 1984, que declaró no haber lugar al recurso de casación contra la anterior.

Afirmaba el actor que las resoluciones judiciales impugnadas vulneraron sus derechos fundamentales al secreto de las comunicaciones (art. 18.3 de la Constitución) y a un proceso judicial con todas las garantías (art. 24.2 de la Norma fundamental). Se consideró procedente su despido por infracción de las obligaciones de lealtad y buena fe en sus relaciones para con la empresa basándose en una única prueba que había sido obtenida ilegítimamente, como fue la grabación fonográfica de la conversación telefónica por el recurrente con otra persona, sin su consentimiento, produciéndose la vulneración del art. 18.3 CE y del art. 24.2 CE (en este último caso, por no gozar de un proceso con todas las garantías, ya que se le despidió en base a una única prueba que a la postre había sido obtenida de forma ilícita). Se trataba, en síntesis, de una conversación telefónica en la que el trabajador despedido estaba coaccionando a un directivo de la empresa para que le ascendiese a cambio de no revelar determinadas informaciones comprometedoras.

\section{b) Análisis de la sentencia}

De entrada, es menester apuntar que algún autor ha comentado que la sentencia que estamos citando es resultado de una larga "travesía del desierto"30; pero ni mucho menos se puede compartir esa opinión. Como hemos observado, en efecto, la exclusiona-

30 Díaz Cabile y Martín Morales (2001)p. 235. 
ry rule aparece en Estados Unidos ciento veinte años después de que se promulgara la Constitución Federal y la Bill of Rights $^{31}$; y en España, sin embargo, la declaración ilícita de una fuente de prueba obtenida violentando derechos y libertades fundamentales aparece solo 6 años después de la promulgación de la Constitución de 1978.

Hay que decir, sin embargo, que antes de esta sentencia se dictaron los AATC 173/1984 de 21 de marzo y 289/1984 de 16 de mayo, en los que se rechazó la tesis recogida luego por aquella (esto es, que se infringiera el derecho a un proceso con todas las garantías -art. 24.2 CE- cuando una fuente de prueba era adquirida violentando los derechos constitucionales). Así, en el Fundamento Jurídico 4 del ATC 173/1984 se dijo:

"Pero dicha argumentación no puede ser admitida con la finalidad pretendida: a) porque no se apoya en ninguna norma de Derecho positivo ni de la Constitución, ya que no existen disposiciones legales en que apoyar tal principio y doctrina; b) porque, a su vez, dicho principio general de Derecho no se encuentra reconocido por la jurisprudencia y, como se reconoce en la demanda, es solo una mera aspiración que han patrocinado de lege ferenda para incorporarla al Derecho positivo civil algunos procesalistas españoles, por no existir actualmente, como se dijo, norma alguna que impida a los órganos judiciales penales valorar los documentos cualquiera que sea su origen; c) porque, además, no consta se haya planteado por el recurrente dicho tema ante el Juzgado Central y en apelación ante la Audiencia, pues ninguna de las dos resoluciones recurridas se refieren a él en absoluto, y la de apelación estudia todas las cuestiones alegadas por las partes con minuciosidad y fundadamente, por lo que se ha traido ante este Tribunal Constitucional per saltum como tema nuevo, contrariando lo dispuesto en el art. 44.1 a) y c) de la LOTC, que hace a esta vía de amparo subsidiaria; d) porque en todo caso serian necesarias expresas declaraciones de los Tribunales competentes sobre la existencia de la sustracción de documentos de carácter delictivo o ilicito, para poseer el indispensable soporte fáctico-judicial sobre el que poder apoyar consecuencias jurídicas como la alegada, al no servir la mera invocación y estimación de la parte por si sola, en cuanto supone una simple alegación a la que no pueden unirsele consecuencias, y e) porque, finalmente, de haberse superado todas esas ausencias, se trataría de un problema de mera legalidad, totalmente ajeno al control de este Tribunal, que incluso podría ser objeto de la fase plenaria del proceso penal, por rebasar el contenido instructorio del sumario, en donde podría valorarse dicho origen y el alcance de las pruebas a través del amplio contenido de convicción psicológica que permite el art. 741 de la L.E.C., para señalar la culpabilidad o inocencia que fuere procedente proclamar. Todo lo que en conclusión determina la clara inexistencia de defecto abstractamente alegado de no haberse otorgado al actor un proceso con todas las garantías legales".

${ }^{31}$ La Constitución de los Estados Unidos de América fue adoptada en su forma original el 17 de septiembre de 1787 y la Enmiendas I a X, que integran la originaria Bill of Rights, datan del 15 de diciembre de 1791. 
En consecuencia, los puntos c) y d) del fundamento transcrito dejan en claro que según el propio Tribunal Constitucional, no se podía prohibir la utilización de piezas de convicción obtenidas ilegítimamente porque tal prohibición, como se dijo, no se encuentra "en ninguna norma de derecho positivo ni de la Constitución", ni tampoco está "reconocida por la jurisprudencia". Tal criterio, sin embargo, es desechado solo meses después por el mismo TC, en la sentencia 114/1984.

En el ATC 289/1984, por su parte, se sigue la misma línea del auto anteriormente citado; su Fundamento Jurídico 4, en fin, dice exactamente lo mismo que el Fundamento Jurídico 4 del ATC 173/1984.

Muy poco tiempo después, entonces, se produce un cambio radical en la postura recién apuntada. El 26 de noviembre de 1984, según se dijo, la Sala Segunda del TC dicta la STC 114/1984, donde abandona por completo el sistema tradicional de admisión y valoración de materiales probatorios e instaura, en cambio, con una fundamentación improvisada y débil al decir de Fidalgo ${ }^{32}$, "la regla de la inadmisión de los materiales probatorios obtenidos o aportados al proceso en violación de los derechos fundamentales". Según el autor mencionado, en fin, la fundamentación de la sentencia fue improvisada y débil porque, a su entender, no existía efectivamente ninguna norma en España que hablara de la obtención ilícita de la fuente de prueba, con lo que el TC estaría equiparando así la prueba prohibida (refiriéndose en realidad a la prueba ilícita) a la prueba impertinente. Hoy en día tal confusión no podría existir en modo alguno por cuanto, como lo señala expresamente el artículo 283.1 LEC, una cosa es la prueba ilícita y otra muy distinta es la prueba pertinente (que es aquella que guarda relación con el objeto del proceso, otorgándose por lo mismo al juez o tribunal la facultad de no admitir una prueba que no tenga relación con el caso que se está dilucidando en el proceso).

Como sea, este cambio radical de criterio es justificado de cierto modo por el TC al señalar que, a fin de cuentas, no se ha producido en realidad tal modificación de postura doctrinal pues, en los casos anteriores, en que se aplicó efectivamente la tesis contraria, "el actor se limitó a invocar abstractamente una doctrina, sin especifica apoyatura constitucional, y a declarar, no menos genéricamente, graves infracciones juridicas producidas en la obtención de los instrumentos probatorios cuya utilización atacó" (F. J. $4^{\circ}$ ). Agrega, luego, que ese defecto abstractamente invocado por aquellos recurrentes "no podia, en verdad, ser objeto de atención por el Tribunal, máxime cuando, como también se indicó, la ilicitud invocada en la creación de la prueba hubiera requerido la declaración en tal sentido del Tribunal competente... Por ello -y porque, según se dijo, el actor no enlazó en modo alguno la alegada ilicitud en la obtención de la prueba con la defensa de derecho fundamental alguno violado por tal formación irregular - el Tribunal hubo de declarar entonces que el problema planteado era de mera legalidad y ajeno, en cuanto tal, al ámbito del amparo constitucional".

Fidalgo $^{33}$ insinúa, por último, que esta contrariedad entre los autos citados y la STC $114 / 1984$ se pueda explicar, talvez, por la especial naturaleza del asunto tratado en el

32 Fidalgo Gallardo (2003) p. 24.

33 Fidalgo Gallardo (2003) p. 22. 
proceso penal que dio lugar a los dos recursos de amparo inadmitidos en los Autos precitados ("caso RUMASA"34), adoptándose por lo mismo -dice- una decisión que debe insertarse en el especial contexto político en el que se dictaron estos pronunciamientos.

Pues bien, y como hemos dicho ya varias veces, al momento de dictar esta sentencia no existía ninguna norma legal que hablara de la obtención ilícita de la fuente de prueba. Por ello, la pregunta que nos tenemos que hacer ahora es: ¿en qué se apoyó entonces el Tribunal Constitucional para adoptar esta histórica decisión? Revisemos este importante aspecto por separado:

a) En el primer F. J. se dice que el recurso de amparo se funda en que se habría admitido en juicio una prueba ilícita, pues para obtenerla se habrían infringido derechos fundamentales (en concreto el contemplado en el art. 18.3 CE).

$\mathrm{Al}$ respecto, la sentencia parte aclarando que la justificación y el sentido institucional del recurso de amparo consiste "en la depuración de las actuaciones de estos órganos [jurisdiccionales] que 'de modo inmediato y directo' (art. 44. 1. b LOTC) hayan incurrido en dichas vulneraciones, no siendo este proceso constitucional instrumento apto para revisar genéricamente lo resuelto por la justicia ordinaria”. La infracción supuesta del art. 18.3 CE -continúa el fallo- no podría imputarse sin embargo a la actuación del tribunal, sino a actos extraprocesales. Por lo mismo, y no existiendo infracción directa alguna en el acto de admitir una prueba en juicio, por el medio de prueba idóneo establecido para ello en la ley, el TC parte declarando que el razonamiento del recurrente no puede compartirse.

b) Pese a lo anterior, en el F. J. $2^{\circ}$ se afirma que efectivamente "no existe un derecho fundamental autónomo a la no recepción jurisdiccional de las pruebas de posible origen antijurídico". A continuación sin embargo (y de aquí el mérito de la sentencia, como tributaria del sistema de protección de derechos fundamentales que consagra la Carta Magna), se aclara que lo anterior no obsta a que en determinados casos puedan inadmitirse pruebas en el proceso, si estas provienen de la infracción de un derecho fundamental. Por la trascendencia de este razonamiento, preferimos citar aquí las palabras del TC:

"En el caso aqui planteado, lo que en realidad reprocha el actor a las actuaciones judiciales es haber decidido a partir de una prueba ilícitamente obtenida. Haya ocurrido asi o no, lo cierto es que no existe un derecho fundamental autónomo a la no

\footnotetext{
34 RUMASA (Ruiz Mateos Sociedad Anónima) fue un holding de empresas españolas expropiado por el gobierno español del PSOE el 23 de febrero de 1983, en virtud del Decreto-Ley 2/1983. El Consejo de Ministros del Gobierno de España decretó la expropiación forzosa del holding al amparo de las previsiones contenidas en los artículos 33. 3 y 128. 2 de la Constitución española, aduciendo como razones para ello las siguientes:

- La reiterada falta de auditorías externas a los bancos del grupo como de sus sociedades más importantes (desde el año 1978).

- La permanente obstrucción a la actividad inspectora del Banco de España.

- Los desproporcionados riesgos asumidos por los bancos que financiaban internamente al grupo con respecto de la solvencia del grupo.

- La desatención a las múltiples advertencias de las autoridades monetarias a RUMASA, recomendando una política más prudente de inversiones y una desconcentración de riesgos.

- La arriesgada espiral de adquisiciones e inversiones del grupo.
} 
recepción jurisdiccional de las pruebas de posible origen antijuridico. La imposibilidad de estimación procesal puede existir en algunos casos, pero no en virtud de un derecho fundamental que pueda considerarse originariamente afectado, sino como expresión de una garantía objetiva e implicita en el sistema de los derechos fundamentales, cuya vigencia y posición preferente en el ordenamiento puede requerir desestimar toda prueba obtenida con lesión de los mismos. Conviene por ello dejar en claro que la hipotética recepción de una prueba antijurídicamente lograda, no implica necesariamente lesión de un derecho fundamental. Con ello no quiere decirse que la admisión de la prueba ilícitamente obtenida -y la decisión en ella fundamentada- hayan de resultar siempre indiferentes al ámbito de los derechos fundamentales garantizados por el recurso de amparo constitucional. Tal afectación y la consiguiente posible lesión no pueden en abstracto descartarse, pero se producirán solo por referencia a los derechos que cobran existencia en el ámbito del proceso (art. 24. 2 de la Constitución)”. En sintesis, no existe una norma expresa en nuestra Constitución sobre la obtención ilícita de la fuente de prueba, pero si existen supuestos en que se debe inadmitir como exigencia "objetiva e implícita" del "sistema de los derechos fundamentales".

c) A continuación, y para justificar la afirmación arriba transcrita, el Tribunal se apoya en la construcción jurisprudencial de la Suprema Corte de los Estados Unidos de Norteamérica, señalando:

“... puede traerse a colación la doctrina establecida por la Corte Suprema de los Estados Unidos respecto de la evidence wrongfully obtained y de la exclusionary rule, en cuya virtud, en términos generales, no puede admitirse judicialmente el material probatorio obtenido con violación de la IV Enmienda a la Constitución. Así, en United States v. Janis $(1976)^{35}$, la Corte declaró que '... la regla por la que se excluye la prueba obtenida en violación de la IV Enmienda tiende a garantizar los derechos generalmente reconocidos en dicha enmienda a través de un efecto disuasorio (de la violación misma) y no tanto como expresión de un derecho constitucional subjetivo de la parte agraviada..."'36.

d) Luego, en el F. J. $3^{\circ}$ se explican más detalladamente los argumentos utilizados en el Fundamento Jurídico $2^{\circ}$ :

“...si la ilicitud en la obtención de la prueba fuese cierta y si fuese posible inferir de nuestro ordenamiento una regla que imponga su ineficacia procesal, habría que concluir que la decisión jurisdiccional basada en tal material probatorio pudo afectar a

\footnotetext{
35 Según Fidalgo, la cita es errónea por cuanto, al dictarse esta sentencia, la regla de exclusión se encontraba ya en desuso por la jurisprudencia mayoritaria. Por ello, la sentencia mencionada no refleja según este autor "el proceso de declive y contestación en que se encontraba la exclusionary rule ya en el momento de ser dictada, después de haber pasado su momento de mayor extensión y vitalidad a principios de los años sesenta", FidALGO GALLARDO (2003) p. 27.

${ }^{36}$ F. J. 2 STC 114/1984 de 26 de noviembre.
} 
los derechos fundamentales del recurrente a un proceso con todas las garantías (art. 24.2 de la Constitución) y, en relación con ello, al derecho a la igualdad de las partes en el proceso (art. 14 de la Constitución)".

En este Fundamento Jurídico $3^{\circ}$, el TC pone en evidencia que no existía en aquel momento en el ordenamiento español una norma que "imponga la no consideración como prueba de aquellas propuestas por las partes y obtenidas antijurídicamente", lo que implicaba que cualquier decisión en tal sentido, no obstante la inclinación doctrinaria para inadmitir prueba de fuente ilícita, estaría fundada en la consideración puramente subjetiva del juzgador en cuanto a la impertinencia o inutilidad de la prueba (art. 566 de la LEC). Por lo demás, tal decisión apuntaría al contenido de la prueba y no, en lo que aquí interesa, a las "circunstancias que hayan podido presidir la forma de su obtención".

En ese mismo Fundamento Jurídico se pone énfasis también en la completa ausencia de líneas jurisprudenciales uniformes en el Derecho comparado, tanto en los países del common law como en Francia, Italia e incluso en el Derecho comunitario. Pese a ello, el TC acude al Derecho comparado como apoyo para dictaminar su fallo, señalando en el precitado Fundamento Jurídico $3^{\circ}$ :

"Por lo general, los paises de "common law" hacen prevalecer el interés público en la obtención de la verdad procesal sobre la posible causa ilícita de la prueba, con la muy notable excepción del Derecho norteamericano, en el que se rechaza la prueba ilegalmente obtenida, si bien solo cuando la actuación irregular y contraria a un derecho constitucional se realizó por un agente público. Una solución parcialmente análoga ha prevalecido en el Derecho francés, en el que al menos parte de la jurisprudencia se inclina a considerar como "nula" toda prueba obtenida mediante registro ilegitimo de conversaciones telefónicas (así, en este sentido, Sentencia del Tribunal de Casación de 18 de marzo de 1955). En el ordenamiento italiano, el debate doctrinal acerca de la procedencia de las pruebas ilegalmente obtenidas ha quedado parcialmente zanjado -por lo que se refiere a las pruebas específicamente "inconstitucionales"- en la Sentencia núm. 34, de 1973, de la Corte Constitucional, y en la Ley núm. 98/1974, por la que se reformó el Código de Procedimiento Penal en el sentido establecido en la citada decisión jurisdiccional. La Sentencia de la Corte declaró que "... el principio enunciado en el apartado primero de la norma constitucional (art. 15: libertad y secreto de las comunicaciones) quedaría gravemente comprometido si, por parte del interesado, pudieran valer como indicios o pruebas interceptaciones telefónicas obtenidas ilegalmente, sin previa resolución judicial motivada".

En síntesis, con base en el derecho comparado antes mencionado y sobre todo en los arts. 10. 1, 24.2 y 14, todos de la CE, se inaugura en España la doctrina de que las fuentes de prueba obtenidas ilícitamente no pueden surtir efectos en el proceso, reconociéndose definitivamente así la posición preferente e inviolable que se atribuye a los 
derechos fundamentales cuando ellos colisionan con la búsqueda de la verdad formal a la que ya nos hemos referido ${ }^{37}$.

\subsubsection{La doctrina de los frutos del árbol envenenado en la jurisprudencia del TC.}

Por las especiales características, alcances y manifestaciones jurisprudenciales que ha tenido en España la denominada "doctrina del árbol envenenado", originada también en la jurisprudencia de la Suprema Corte de los Estados Unidos de Norteamérica, hemos preferido abordar el análisis de las sentencias del TC en forma separada.

$\mathrm{Al}$ respecto, se ha dicho ya que la doctrina de los frutos del árbol envenenado se inaugura en el Derecho español con la STC 86/1995 de 6 de junio ${ }^{38}$. Sin embargo, nos detendremos únicamente aquí en el análisis de la STC 81/1998, de 2 de abril, por reflejarse en ella un sustancial cambio en la doctrina del TC sobre esta materia, innovando por ende respecto de la que venía sosteniendo en fallos anteriores ${ }^{39}$.

En esta sentencia, que también trata de la eficacia refleja de la prueba ilícita, el TC no centra ya su argumentación en la existencia de una "conexión causal" entre la prueba ilícita y la que surge indirectamente de ella, a que se refirió en las sentencias anteriores, sino que requiere ahora la concurrencia de una "conexión de antijuridicidad".

37 Otras sentencias sobre prueba de fuente ilícita que pueden consultarse son: STC 384/1993 de 21 de diciembre; STC 50/2000 de 29 de marzo; STC 299/2000 de 11 de diciembre; STC 68/2001 de 17 de marzo, 138/2001 de 18 de junio, 10/2002 de 8 de febrero, 123/2002 de 20 de mayo, 2/2003 de 16 de febrero, 233/2005 de 26 de septiembre, 259/2006 de 3 de julio, 261/2005 de 24 de octubre, 26/2006 de 30 de enero, $198 / 2006$ de 3 de julio y 253/2006 de 11 de octubre.

38 De esta sentencia interesa destacar especialmente la exigencia que hace el TC en cuanto a la concurrencia de una conexión causal entre los resultados probatorios, para que se dé una ineficacia refleja de la prueba ilícita. Dice al respecto la sentencia:

"El derecho al secreto de las comunicaciones solo puede ser limitado mediante una resolución judicial suficientemente motivada. La existencia de un mandamiento judicial autorizando la intervención, junto con la estricta observancia del principio de proporcionalidad en la ejecución de esta diligencia de investigación, constituyen exigencias constitucionalmente inexcusables que afectan al núcleo esencial del derecho al secreto de las comunicaciones, de tal modo que la ausencia de autorización judicial o la falta de motivación determinan, irremediablemente, la lesión del derecho constitucional y, por lo tanto, la prohibición de valoración de cualquier elemento probatorio que pretenda deducirse del contenido de las conversaciones intervenidas, no solo del resultado mismo de la intervención, sino de cualquier otra prueba derivada de la observación telefónica, siempre que exista una conexión causal entre ambos resultados probatorios. Así, hemos tenido ocasión de declarar que "una vez establecido que la intervención del teléfono vulneró su derecho al secreto de las comunicaciones, reconocido en el art. 18. 3 C. E., hemos de concluir que todo elemento probatorio que pretendiera deducirse del contenido de las conversaciones intervenidas no debió ser objeto de valoración probatoria.

En el presente caso, en contra de lo que sostiene el Ministerio Público y la propia resolución impugnada, existe una relación de causalidad entre la ocupación de la droga y el resultado de la observación telefónica ilícita" (STC 85/1994, fundamento juridico 4)".

39 Sobre la doctrina del TC, hasta la sentencia 81/1998, pueden consultarse: STC 85/1994 de 14 de marzo, que sirvió de antecedente de la STC 86/1995; STC 138/2001 de 18 de junio; STC 167/2002 de 18 de agosto. En cuanto a la jurisprudencia del Tribunal Supremo, pueden consultarse la STS de 24 de octubre de 2003 y la STS de 15 de junio de 2004. Sobre la jurisprudencia de las Audiencias Provinciales, por último, pueden consultarse las siguientes sentencias: SAP de Pontevedra, de 18 de noviembre de 2002; SAP de Santander de 22 de junio de 2005; SAP de Madrid de 12 de julio de 2005; SAP de Santander de 4 de abril de 2006. 
A modo de síntesis, el TC aclara aquí que las pruebas cuestionadas desde una perspectiva constitucional no resultan por sí mismas contrarias al derecho fundamental que se dice infringido (en el caso examinado por la sentencia, el derecho al secreto de las comunicaciones telefónicas) ni, por lo mismo, al derecho a un proceso con todas las garantías. Será entonces el origen inconstitucional de esa prueba $-o$ la que de ella se derive- la que determine entonces su exclusión; pero si las pruebas de que se trata no guardan relación con el hecho que se dice constitutivo de esa infracción del derecho fundamental o, en palabras del propio TC, "si tuviesen una causa real diferente y totalmente ajena al mismo", nada podría objetarse en cuanto a su validez en el proceso.

En este último sentido, y tras reiterar su doctrina general en cuanto a que "todo elemento probatorio que pretenda deducirse a partir de un hecho vulnerador del derecho fundamental al secreto de las comunicaciones telefónicas se halla incurso en la probibición de valoración ex art. 24.2 C. E.", el TC advierte sin embargo que los derechos fundamentales no tiene carácter ilimitado ni absoluto, recordando que, por lo mismo y en circunstancias especiales, ha aceptado pruebas que si bien venían vinculadas a los hechos constitutivos de la infracción del derecho fundamental (por derivar del conocimiento adquirido a partir de tal vulneración), eran no obstante jurídicamente independientes de él. En palabras del propio tribunal (F. J. 4º), en consecuencia, el problema que aquí se plantea consiste en definir "la ratio de la interdicción de la valoración de las pruebas obtenidas a través del conocimiento derivado de otra realizada vulnerando el derecho (fundamental) ..., para poder establecer si estamos ante un supuesto en que debe aplicarse la regla general ..., extendiendo, en consecuencia, la probibición de valoración a las pruebas derivadas o reflejas; o, por el contrario, nos hallamos ante alguna de las hipótesis que permiten excepcionarla" (el paréntesis es nuestro).

En síntesis, el TC concluye que las pruebas reflejas a que nos referimos aquí son intrínsecamente legítimas en su lectura constitucional. Por lo mismo, para concluir lo contrario (esto es, que la exclusión probatoria se extiende también a ellas), "habrá de precisarse que se hallan vinculadas a las que vulneraron el derecho fundamental sustantivo de modo directo, esto es, habrá que establecer un nexo entre unas y otras que permita afirmar que la ilegitimidad constitucional de las primeras se extiende también a las segundas (conexión de antijuridicidad)" 40 . Por tanto, según este fallo habrá que tener en cuenta dos cuestiones para excluir o no las pruebas derivadas de otras pruebas constitucionalmente ilícitas:

\footnotetext{
40 Precisando los criterios que deben seguirse para determinar la concurrencia o no de esta "conexión de antijuridicidad", la sentencia señala en su F. J. 4": "Para tratar de determinar si esa conexión de antijuridicidad existe o no, hemos de analizar, en primer término la indole y caracteristicas de la vulneración del derecho al secreto de las comunicaciones materializadas en la prueba originaria, asi como su resultado, con el fin de determinar si, desde un punto de vista interno, su inconstitucionalidad se transmite o no a la prueba obtenida por derivación de aquella; pero también hemos de considerar, desde una perspectiva que pudiéramos denominar externa, las necesidades esenciales de tutela que la realidad y efectividad del derecho al secreto de las comunicaciones exige. Estas dos perspectivas son complementarias, pues solo si la prueba refleja resulta juridicamente ajena a la vulneración del derecho y la prohibición de valorarla no viene exigida por las necesidades esenciales de tutela del mismo cabrá entender que su efectiva apreciación es constitucionalmente legitima, al no incidir negativamente sobre ninguno de los aspectos que configuran el contenido del derecho fundamental sustantivo (STC 11/1981, fundamento jurídico 8).
} 
a) Apreciar en primer término, respecto del derecho fundamental de que se trate, en qué sentido o aspecto ha sido vulnerado ese derecho (presupuestos materiales, intervención y control judicial, proporcionalidad, expresión de todas y cada una de las exigencias constitucionales) y de qué forma lo ha sido (F. J. 50), para a partir de esto comprobar si la violación del derecho fundamental por el que se ha obtenido la fuente de prueba fue "indispensable o determinante" para obtener la prueba derivada de esa prueba constitucionalmente ilícita. En este aspecto entonces, la tesis propuesta -en nuestro concepto- parece fundarse en la denominada "doctrina del descubrimiento inevitable", comentada supra ${ }^{41}$.

b) Sopesar si el derecho fundamental en cuestión es de fácil vulneración o no. En caso de serlo los resultados probatorios derivados de su infracción no se deberían excluir y por tanto producir efectos en el proceso.

Nos parece, sin embargo, que el criterio apuntado implica, tal como se plantea por el TC, dejar entregada al intérprete la definición del contenido y alcance de los derechos fundamentales que pudieren verse afectados en la labor de obtención de la fuente de prueba, por la vía de determinar en cada caso -sin sujeción a patrones estrictamente objetivos- cuáles son "más o menos vulnerables".

Por último, y dicho lo anterior, surge de inmediato en esta parte la siguiente interrogante: ¿A qué se debe este cambio de postura en la doctrina del TC?

Como dice Martínez ${ }^{42}$, el origen de esta suerte de golpe de timón parece encontrarse en la alarma social que al momento de dictarse esta sentencia se hacía sentir en España, ante el aumento de la criminalidad y la inseguridad, circunstancia que habría llevado al TC a cambiar de orientación. En la STC 86/1995 se excluía de valoración judicial tanto las pruebas directamente inconstitucionales como aquellas que se deriven de las anteriores siempre que existiera una conexión causal entre ambos resultados probatorios. En la STC 81/1998, en cambio, para que la exclusión probatoria se produzca es necesario que exista entre una y otras una "conexión de antijuridicidad", es decir, no solo hay que determinar, de forma unilateral y única, si la ilicitud se transmite de una prueba a otra dada "la indole y características de la vulneración" del derecho fundamental de que se trate, sino también complementar el anterior examen con una "perspectiva que pudiéramos denominar externa", relacionada con "las necesidades esenciales de tutela que la realidad y efectividad del derecho exige" 43 .

\section{LA OBTENCIÓN ILÍCÍTA DE LA FUENTE DE LA PRUEBA EN EL ORDENAMIENTO PROCESAL CHILENO}

En los acápites anteriores hemos pasado breve revista del estado actual de la legislación española y, antes que ella, a la evolución jurisprudencial que le sirvió de antecedente en punto a la fuente de la prueba y su obtención ilícita en el proceso civil.

${ }^{41}$ Montero Aroca (1998) pp. 72 y 73, mencionado también por SANCHIS Crespo (1999) pág. 70.

42 Martínez García (2005) p. 501.

43 Garberí Llobregat y Buitrón Ramírez (2004) p. 128. 
Esa evolución, plasmada hoy en normas legales expresas de la LOPJ y la nueva LEC, ya citadas, constituyen sin duda una valiosa herramienta procesal que se orienta, de manera directa, a poner de relieve el respeto y preeminencia de los derechos fundamentales que puedan verse afectados y puestos en juego ante la actividad probatoria de los operadores procesales.

En lo que constituye entonces una clara opción jurídico-valórica, que informa actualmente y por lo demás a la mayoría de los ordenamientos jurídicos comparados, se privilegia de este modo la observancia y el resguardo de los derechos considerados por la sociedad como esenciales e inherentes a la persona humana, frente a la obtención a ultranza de la verdad como fin y propósito único del proceso.

Nos proponemos revisar sucintamente a continuación, por la indudable relevancia que representa el tema bajo análisis, el estado actual de la normativa constitucional y procesal chilena sobre este aspecto, con el solo propósito de formular algunas observaciones al respecto y presentar en torno a ellas las conclusiones que puedan ser pertinentes.

\section{CONSIDERACIONES GENERALES SOBRE LA PRUEBA COMO DERECHO EN LA CONSTITUCIÓN DE 1980}

Como señala una parte de la doctrina, en Chile se ha llegado a un consenso en torno a la existencia de un denominado "derecho a la prueba", lo que por cierto trasciende y supera ampliamente la concepción tradicional de la actividad probatoria como mera carga procesal ${ }^{44}$. La discusión se ha centrado sin embargo, especialmente, en determinar si este derecho a la prueba es autónomo o si, por el contrario, constituye una manifestación del más amplio "derecho de defensa", que consagra el artículo $19 \mathrm{~N}^{\circ} 3$, inciso $2^{\circ}$, de la Constitución de 1980, en cuya virtud se le asegura a todas las personas el derecho a intervenir en el proceso de formación de la decisión jurisdiccional, formulando sus pretensiones y contradiciéndolas en un plano de igualdad. Así entendido el derecho que comentamos, Carocca lo define como "la garantía constitucional autónoma, que confiere a todo litigante, la facultad de producir las probanzas que requiere para demostrar la efectividad de sus alegaciones de hecho" 45 . El Tribunal Constitucional español, por su parte, distingue también entre ambos derechos al pronunciarse sobre el contenido y alcance del artículo 24.2. de la Constitución española de 1978, aunque los califica al mismo tiempo de "inseparables" 46.

\footnotetext{
${ }^{44} \mathrm{Al}$ respecto puede consultarse a CAROCCA PÉREZ (2003).

45 Carocca PÉrez (2003).

46 Así por ejemplo en la sentencia $\mathrm{N}^{\circ}$ 30/1986, de 20 de febrero, en cuyo fundamento $8^{\circ}$ señala: “...el art. 24. 2 de la Constitución ha convertido en un derecho fundamental el de "utilizar los medios de prueba pertinentes" en cualquier tipo de proceso en que el ciudadano se vea involucrado. Este derecho fundamental, inseparable del derecho mismo a la defensa, consiste en que las pruebas pertinentes propuestas sean admitidas y practicadas por el Juez o Tribunal y, al haber sido constitucionalizado, impone una nueva perspectiva y una sensibilidad mayor en relación con las normas procesales atinentes a ello, de suerte que deben los Tribunales de Justicia proveer a la satisfacción de tal derecho, sin desconocerlo ni obstaculizarlo, siendo preferible en tal materia incurrir en un posible exceso en la admisión de pruebas que en su denegación". RTC 1986130, en Aranzadi Westlaw.
} 
No es nuestro propósito el detenernos aquí en el análisis de una u otra postura doctrinal, sino simplemente el destacar que la actividad probatoria de las partes constituye, necesariamente, uno de los elementos o requisitos indispensables para dar contenido y hacer eficaz el derecho que se consagra en el artículo $19 \mathrm{~N}^{\circ} 3$ ya citado, por lo que su observancia es obligatoria para el propio legislador, para el juez y para las partes en juicio.

Del mismo modo, el artículo $19 \mathrm{~N}^{\circ} 3$ ya citado, ahora en su inciso $5^{\circ}$, consagra también como derecho fundamental el denominado "debido proceso", señalando que "toda sentencia de un órgano que ejerza jurisdicción debe fundarse en un proceso previo legalmente tramitado", agregando luego que "corresponderá al legislador establecer siempre las garantías de un procedimiento y una investigación racionales y justos". Por lo mismo, la decisión del asunto controvertido a que se refiere el artículo $170 \mathrm{~N}^{\circ} 6$ del Código de Procedimiento Civil, comprensiva de todas las acciones u excepciones que se hayan hecho valer por las partes, solo puede ser expresión de un proceso racional y justo si a las partes se les reconoce y asegura el derecho a la prueba y, a través de él, de allegar al proceso los elementos que permitan el pronunciamiento jurisdiccional que requieren.

El derecho a la prueba, en síntesis, presupone que el tribunal predeterminado por la ley admita la prueba ofrecida; a que esta sea efectivamente practicada en el proceso con intervención o audiencia de las demás partes en litigio; y a que -por último- la prueba sea debidamente ponderada por el tribunal, precisando además las que se rechazan y las motivaciones de tal determinación.

\section{LA EXCLUSIÓN DE LA PRUEBA DE FUENTE ILÍCITA COMO LÍMITE Y SANCIÓN AL EJERCICIO ILEGÍTIMO DEL DERECHO A LA PRUEBA}

Según se dijo en el párrafo precedente, podemos afirmar entonces la existencia de un denominado "derecho a la prueba", consagrado y tutelado en la Carta Política de Chile de 1980, ya sea que se lo considere de manera autónoma o que se lo entienda formando parte del "derecho a la defensa", también mencionado.

Sin embargo, y con base ahora en lo que se ha dicho en los capítulos anteriores, debemos afirmar al mismo tiempo que ese derecho -o la actividad probatoria que de él se deriva- debe ser ejercido, a la luz de los demás derechos esenciales que la misma Constitución le reconoce a las personas, en un plano de realización proporcionada y armónica de unos y otros. Dicho en otros términos, el justiciable no tendrá derecho alguno a la prueba en aquellos casos en que para obtenerla ha violentado determinados derechos fundamentales, pues, simplemente, en tales casos ese derecho no ha llegado siquiera a existir. Como señala Sanchis ${ }^{47}$, en efecto, "si el órgano jurisdiccional entiende que debe inadmitir un medio de prueba es porque considera que no se tiene derecho a utilizarlo. Cualquier consecuencia ulterior -como es la de inadmitir motivada, razonable y no arbitrariamente- está presuponiendo la inexistencia del derecho, por lo que mal puede integrar su contenido".

47 SANCHIS CRESPO (1999). 


\subsection{Derechos fundamentales que pueden verse afectados por la actividad de obtención de la fuente de prueba}

No pretendemos en este parágrafo abarcar todas las posibilidades de infracción de derechos fundamentales que pueden presentarse en la actividad de pesquisa de la fuente de prueba (o "heurística", según se ha denominado a esta actividad por alguna doctrina), como el derecho a la vida y a la integridad física y psíquica consagrado en el artíclo 19 $\mathrm{N}^{\circ} 1$; a la libertad de conciencia contemplado en el artículo 19 No 6; o el derecho a la libertad personal y seguridad individual del artículo 19 No 7 , entre otros (sin perjuicio de aquellos reconocidos en los Tratados sobre Derechos Humanos ratificados por Chile, en virtud del artículo $5^{\circ}$ de la Constitución). Simplemente, nos proponemos mencionar aquellos derechos que, por su propia naturaleza, pueden aparecer como más vulnerables ante la actividad probatoria de las partes en conflicto en un proceso civil, particularmente en la tarea extraprocesal o de búsqueda de las fuentes para su ulterior introducción al juicio, por los medios de prueba legal.

Hacemos presente lo anterior por cuanto, según se dijo antes, el origen y desarrollo de la figura de la prueba ilícita surgió en el marco del proceso penal norteamericano y, más concretamente, como creación jurisprudencial tendiente a controlar los excesos e imperfecciones de un sistema procesal en donde la instrucción se encuentra entregada al Ministerio Público y también a la policía. Por lo mismo, la finalidad con que se diseñó y desarrolló esta construcción jurisprudencial consistió precisamente, en tal escenario, en restringir o al menos delimitar las facultades del Ministerio Público y en particular de la policía en sus actividades de pesquisa, considerando que en el proceso penal, en efecto, el imputado o acusado asume muchas veces la calidad de objeto de la prueba que deben procurarse los órganos de instrucción. Por ello, y como señala la doctrina ${ }^{48}$, es en el proceso penal en donde la prueba ilícita adquiere toda su significación, pues en la tarea de búsqueda de la verdad material y de existencia del delito por los órganos de instrucción -y en último término por el Estado- pueden fácilmente violentarse derechos esenciales del acusado, como ocurriría con una declaración obtenida mediante coerción o derechamente con tortura; con la intercepción de conversaciones telefónicas no autorizadas en forma legal; con los registros o intervenciones corporales realizadas indebidamente, etc.

En el proceso civil en cambio, inspirado en el principio dispositivo y de oportunidad, son las partes las encargadas de obtener las fuentes y aportar los elementos de prueba al proceso, en la medida que resulten esenciales y pertinentes. Por lo mismo, la condición de igualdad procesal que existe necesariamente entre los litigantes determina que, en esta clase de conflictos, los derechos fundamentales que pueden verse afectados por la actividad probatoria de los mismos se sitúen comúnmente en la esfera de la intimidad y dignidad, en sus manifestaciones constitucionales de protección de la vida privada e inviolabilidad del domicilio, más que en el ámbito de posibles atentados a la integridad física y psíquica de las personas (como podría ocurrir con la actividad de los órganos de instrucción en el proceso penal). Lo anterior no implica sin embargo, en

${ }^{48}$ Gimeno SENDRA (2005) p. 136. 
modo alguno, excluir esta última posibilidad de infracción en el proceso civil (como sería el caso de un testigo que deponga bajo coacción de alguna de las partes); lejos de eso, lo que decimos es simplemente que tales atentados pueden ser comparativamente de menor ocurrencia que en el proceso penal, al no existir todo un aparato estatal que ejerza de manera privativa el ius puniendi, teniendo muchas veces -según se dijo- al propio imputado como objeto de prueba.

Dicho lo anterior, el derecho a la intimidad y el honor se encuentran consagrados en la Constitución de 1980, como derechos fundamentales, en el artículo $19 \mathrm{~N}^{\circ} 4$ y $\mathrm{N}^{\circ}$ 5 de la Carta Política. Señala al respecto la Carta Política:

"Art. 19 La Constitución asegura a todas las personas:

$4^{0}$ El respeto y protección a la vida privada y pública y a la honra de su persona y de su familia.

$5^{\circ}$ La inviolabilidad del hogar y de toda forma de comunicación privada. El hogar solo puede allanarse y las comunicaciones y documentos privados interceptarse, abrirse o registrarse en los casos y formas determinados por ley".

Como señala Ríos ${ }^{49}$, refiriéndose al primero de los derechos mencionados, "la protección de la vida privada es considerada por el constituyente como un derecho de la personalidad", que atañe -en palabras del profesor Alejandro Silva Bascuñán en la Comisión de Estudio de la Nueva Constitución de 1980, citado por el anterior- a "todo lo relativo al santuario íntimo de la persona, como son el respeto a su propia intimidad, a su propio honor". Por lo mismo, es precisamente en esta esfera de protección en donde la exclusión de la prueba de fuente ilícita cobra especial trascendencia, en cuanto límite y sanción para aquellos casos en que las partes, en su afán de procurarse la prueba para sostener los hechos que configuran su pretensión o defensa, se vean estimuladas a traspasar los límites que impone el respeto de la intimidad y honor de la parte contra la cual se hace valer esa prueba en juicio. En consecuencia, pruebas originadas en arbitrios como el seguimiento, la intercepción y grabación ilegal de señales telefónicas, la sustracción de comunicaciones postales, el registro de bienes personales, la filmación clandestina de imágenes mediante artefactos o instrumental tecnológico, etc., deben ser rechazadas por el juez. En este sentido, el artículo 15 de la Ley $\mathrm{N}^{\circ} 19.968$, que crea los Tribunales de Familia en Chile, señala expresamente que el juez "deberá velar durante todo el proceso por el respeto al derecho a la intimidad de las partes...", pudiendo para ello "prohibir la difusión de datos o imágenes referidos al proceso o a las partes; o disponer, mediante resolución fundada, que todas o algunas de las actuaciones del procedimiento se realicen en forma reservada". Nos parece, sin embargo, que más que prohibir la difusión de tales imágenes o datos, el juez está obligado a excluirlas como prueba si constata que se han obtenido con infracción de derechos fundamentales, según lo exige el artículo 31 del mismo cuerpo legal.

${ }^{49}$ Ríos Fueyo (S/D). 
Por su parte, la protección al domicilio y a las comunicaciones que consagra el artículo $19 \mathrm{~N}^{\circ}$, en estrecha vinculación con el $\mathrm{N}^{\circ} 4$ anterior, apunta también a la protección de la intimidad de la persona en su aspecto material pues, como señala el mismo autor, "para que la esfera íntima o la privada de una persona se mantengan intactas, es necesario proteger estos dos aspectos físicos (junto a varios otros, no nombrados en el No 5, como los bienes de uso personal, el equipaje, etc.)", atendiéndose además a la connotación privada que se protege en razón a la destinación que se hace del bien, que no necesariamente a su dominio. En cuanto a las comunicaciones, por último, lo protegido por la norma constitucional serán "correspondencia o mensajes epistolares, telegráficos, telefónicos, radiales, por télex y los emitidos por cualquier otro medio", y por "documentos privados" se entiende "aquellos que las personas lleven consigo, mantengan en su vivienda o tengan en su lugar de trabajo y de que sean dueñas o tenedoras legítimas" 50 .

\subsection{Derecho a la prueba y Estado de Derecho}

De lo dicho hasta aquí concluimos entonces que la actividad probatoria, en su fase previa de búsqueda de fuentes o, luego, en la de aportación de esta última al proceso civil (privativa de las partes por manifestación y como consecuencia del principio dispositivo que informa), no debe mirarse únicamente como manifestación o exteriorización aislada de este derecho a la prueba ni como el puro levantamiento de una carga impuesta por la ley, sin consideración alguna al origen o fuente extraprocesal de esa prueba y a los restantes derechos que puedan estar vinculados a su obtención.

Dicho en otros términos, la prueba en el proceso civil, como actividad fundamental que lo realiza y que le da contenido, no se agota únicamente en procurarle al juez, sin más consideraciones que la sola búsqueda de la verdad a la que ya nos hemos referido (verdad "formal" para una parte de la doctrina), los elementos de constatación de los hechos invocados causa petendi por el actor en su demanda, o de los hechos que configuran las defensas o excepciones del demandado en su reacción. Mucho más que eso, tanto la búsqueda y obtención de las fuentes de esa prueba, cuanto los medios para allegarla al proceso, se insertan en un marco de garantías fundamentales y de derechos subjetivos de las personas que las partes y el tribunal deben respetar y hacer respetar, bajo sanción de excluirse toda prueba obtenida con infracción de tales derechos fundamentales.

Como señala Esparza ${ }^{51}$, los elementos básicos que definen actualmente el Estado de Derecho, según la opinión mayoritaria, pueden enunciarse así: "Imperio de la voluntad general expresada a través de la ley, división de poderes, reconocimiento de los derechos y libertades, sometimiento de la Administración a la legalidad". En consecuencia, no se trata entonces de reconocer un derecho a la prueba absoluto e ilimitado, a costa de violentar otros tantos derechos fundamentales en la tarea de obtención de la fuente probatoria. Lejos de ello, y como lo ha señalado también el TC español, los derechos fundamentales en su conjunto "se incorporan a la vida política de los Estados de

\footnotetext{
${ }^{50}$ Ríos Fueyo (S/D).

51 Esparza Leibar (1995) p. 236.
} 
manera que, rebasando su carácter meramente subjetivo o individual, se constituyen en elementos esenciales del ordenamiento juridico en cuanto que se conciben como pieza clave para la organización de una convivencia verdaderamente humana, justa y pacifica" 52 .

Por lo tanto, el respeto de tales derechos esenciales se impone también en el marco del proceso y de las pruebas que en él se viertan, de manera que si estas, como se dijo, han sido obtenidas en desmedro y con infracción de los derechos y garantías que el Estado de Derecho le reconoce a las personas, deberá restársele toda significación probatoria; y ello aun cuando formalmente no se haya vulnerado norma alguna en el modo de producirla en juicio.

Como señaló también el TC español en su sentencia 114/1984, en fin, recogiendo además la doctrina establecida por la Corte Suprema de los Estados Unidos de Norteamérica sobre la "evidence wrongfully obtained" y la "exclusionary rule" (contenida esta última en la IV y XIV Enmienda) ${ }^{53}$, la resistencia ante la prueba de fuente ilícita se explica precisamente porque en su origen subyace la infracción de derechos fundamentales "que presentan la doble dimensión de derechos subjetivos de los ciudadanos y de elementos esenciales de un ordenamiento objetivo de la comunidad nacional, en cuanto esta se configura como marco de una convivencia humana justa y pacifica" ${ }^{54}$.

Pues bien, en esta parte el legislador chileno ha optado también, explícitamente incluso en el nuevo Código Procesal Penal y en la Ley sobre Juzgados de Familia como se verá a continuación, por privilegiar la plena eficacia del estatuto garantista que la Constitución reconoce a las personas, antes que la obtención de la verdad procesal cuando esta se sustenta en elementos de prueba obtenidos por vías y/o "actuaciones constitucionalmente ilegítimas" 55 .

A igual conclusión debemos llegar en materia de Procedimiento Civil, si consideramos que las razones que han llevado a las legislaciones comparadas a reconocer este instituto de exclusión de la prueba son de carácter general y, por lo mismo, perfectamente aplicables a nuestro proceso civil ${ }^{56}$. Más aún, si bien no existe en Chile un derecho

52 Sentencia del Tribunal Constitucional de 29 de marzo de 1990, en Aranzadi Westlaw, RJ 1990/2647.

53 Pino aclara al respecto que esta regla no constituye en sí misma una exigencia constitucional en el sistema norteamericano, en la medida que se la concibe solo "para prevenir las conductas policiales contrarias a los derechos consagrados en las enmiendas constitucionales". Por eso, en el caso concreto habrá que sopesar -dice-, "el coste de la exclusión de la prueba, frente al efecto disuasorio que provoca esa exclusión. De esta manera, si un policía actuó amparado por un mandamiento judicial o una norma que luego se declaran inconstitucionales, es obvio que el policía no sabía que su actuación provocaba lesión alguna de derecho fundamental, por lo que la exclusión de la prueba obtenida no va a prevenir en el futuro conductas policiales ilícitas. Este es el fundamento a una excepción a la exclusionary rule, la llamada good faith excepto". PINO REYES (S/D).

${ }^{4}$ Así lo había señalado anteriormente el mismo Tribunal Constitucional, en su sentencia $N^{\circ}$ 25/1981, de 14 de julio, Fundamento Jurídico $5^{\circ}$.

${ }^{55} \mathrm{La}$ sentencia $\mathrm{N}^{\circ} 34$ de 1973, de la Corte Constitucional italiana, señaló al respecto: “... las conductas realizadas en contravención de los derechos fundamentales del ciudadano no pueden servir de presupuesto ni de fundamento para actos procesales a instancia de aquel a quien se deban tales actuaciones constitucionalmente ilegitimas".

56 Según este autor, las razones que se han dado en la doctrina comparada para aceptar y consagrar normativamente esta figura son básicamente las siguientes: a) El proceso debe resolver los conflictos "de acuerdo al ordenamiento jurídico", única forma de resguardar el debido proceso. b) Al aceptarse la prueba 
fundamental subjetivo autónomo a la inestimación de la prueba de fuente ilícita, tal desestimación procesal puede concurrir sin embargo "como expresión de una garantía objetiva e implícita en el sistema de los derechos fundamentales, cuya vigencia y posición preferente en el ordenamiento puede requerir desestimar toda prueba obtenida con lesión de los mismos" 57 .

\section{LA PRUEBA DE FUENTE ILÍCITA EN LA LEGISLACIÓN PROCESAL CHILENA}

\subsection{Su reconocimiento explícito en el Código Procesal Penal:}

Advirtamos desde luego que el Código Procesal Penal, en su artículo 295, consagra como regla general en materia de prueba que cualquier elemento probatorio puede ser aportado al juicio para establecer los hechos imputados o los que se invocan en la defensa. Señala este artículo:

"Art. 295. Libertad de prueba. Todos los hechos y circunstancias pertinentes para la adecuada solución del caso sometido a enjuiciamiento podrán ser probados por cualquier medio producido e incorporado en conformidad a la ley".

En virtud de esta disposición entonces, toda y cualesquier restricción a la libertad de prueba se encuentra en principio proscrita por el legislador, la que no puede ser excluida por el tribunal en la medida (a) que esta sea pertinente, (b) que no sea innecesariamente abundante; (c) que no provenga de diligencias declaradas nulas y; (d) en lo que aquí interesa, que sea obtenida sin infringir derechos fundamentales del imputado o de terceros. Así se desprende del artículo 276 inciso tercero del Código Procesal Penal, que señala:

"Artículo 276. - Exclusión de pruebas para el juicio oral. El juez de garantía, luego de examinar las pruebas ofrecidas y escuchar a los intervinientes que hubieren compareci-

de fuente ilícita se estaría infringiendo, como contrapartida, el principio de la probidad o lealtad procesal; c) Como principio de Derecho de general aplicación, los actos ilícitos no pueden beneficiar a su autor, que es precisamente lo que ocurriría de aceptarse la prueba de fuente ilícita. d) Recogiendo los postulados de la doctrina norteamericana, se debe negar valor a esta clase de prueba como "efecto disuasorio" frente a aquellos que pudiesen verse estimulados a procurársela por cualquier vía ilegítima. Agreguemos nosotros que también el Tribunal Supremo español -TS- se ha pronunciado sobre este efecto disuasorio, en sentencia del 29 de marzo de 1990: Dijo allí el TS: “...ante el carácter fundamental que se concede a tales derechos, cuya protección adquiere, incluso, un rango de carácter internacional por el deber contraido por algunos Estados, como España, por convenios pactados con otros, en aras de conseguir el imprescindible efecto disuasorio en sus posibles infractores, a fin de que una violación de este tenor pueda en definitiva prevenirse, e impone la necesidad de estimar radicalmente nula la prueba asi obtenida y, por tanto, sin eficacia alguna en el proceso". e) Si las normas de derecho sustantivo sancionan generalmente con la nulidad el acto material de obtención de esa clase de prueba, "no se divisa por qué no debería extenderse la sanción a la utilización procesal de tales medios”. f) Permitirle a las partes procurarse la fuente de la prueba por cualquier vía, implicaría reconocer implícitamente una forma de autotutela. g) La obtención del elemento probatorio mediante la infracción de derechos fundamentales, para luego presentarlas en juicio por los medios de prueba reconocidos en la ley, importa un acto en fraude de la misma que debe sancionarse. CAROCCA, op. cit.

57 Así lo señaló el TC español en la sentencia 114/1984, de 29 de noviembre, en su Fundamento Segundo. 
do a la audiencia, ordenará fundadamente que se excluyan de ser rendidas en el juicio oral aquellas que fueren manifiestamente impertinentes y las que tuvieren por objeto acreditar hechos públicos y notorios.

Si estimare que la aprobación en los mismos términos en que hubieren sido ofrecidas las pruebas testimonial y documental produciria efectos puramente dilatorios en el juicio oral, dispondrá también que el respectivo interviniente reduzca el número de testigos o de documentos, cuando mediante ellos deseare acreditar unos mismos hechos o circunstancias que no guardaren pertinencia sustancial con la materia que se someterá a conocimiento del tribunal de juicio oral en lo penal.

Del mismo modo, el juez excluirá las pruebas que provinieren de actuaciones o diligencias que hubieren sido declaradas nulas y aquellas que hubieren sido obtenidas con inobservancia de garantías fundamentales.

Las demás pruebas que se hubieren ofrecido serán admitidas por el juez de garantía al dictar el auto de apertura del juicio oral".

En este sentido, la Corte de Apelaciones -CA- de Rancagua ha declarado precisamente:

“... el derecho solo se explica y justifica en función del bien común y dignidad del hombre, asumiendo en nuestra cultura cristiana occidental la exigencia de dotarnos de un régimen de gobierno que se ajuste a lo que genéricamente denominamos un Estado democrático de Derecho, expresión que comprende un estatuto politico institucional caracterizado por un reciproco control de los órganos que ejercen el poder, control que adicionalmente se verifica comprobando la concordancia del actuar con la normativa jurídica predeterminada. La investigación, juzgamiento y sanción de los delitos, representa una tarea insoslayable de los Estados y que, por siglos, la historia del proceso penal, instrumento a través del cual se lleva a cabo esta función estatal, ha oscilado entre lo que con cierta simpleza de análisis se ha denominado garantismo y eficacia, encrucijada que enfrenta la búsqueda de la verdad como mecanismo de defensa social, y la observancia, atención y cuidado de los derechos y garantías constitucionales"

Haciendo directa aplicación de la doctrina de los frutos del árbol envenenado, el mismo fallo recién citado agrega:

“... siendo declarada ilegal una detención, toda la prueba obtenida en razón de dicho acto es ilícita, por obtenerse con inobservancia de garantías constitucionales, debiendo quedar excluida del juicio oral, corriendo igual destino los elementos probatorios que se hayan obtenido en forma derivada...".

En igual sentido se ha pronunciado también la Exma. Corte Suprema -CS-, al declarar la ilicitud de la prueba obtenida con infracción del derecho a la intimidad o

58 SCA Rancagua, de 14 de junio de 2007, Rol No 216-2007. 
Jequier Lehuedé, Eduardo "La obtención ilícita de la fuente de la prueba en el proceso civil..."

privacidad de las personas, consagrado en el numeral 5 del artículo 19 de la Constitución Política de la República:

"CUARTO. ... Las excepciones a que alude la norma (se refiere al art. 19 No 5 recién citado) solo pueden encontrar su legitimación en leyes sustantivas expresas, predispuestas por el legislador para casos especiales y que deben cumplirse con las formalidades que las mismas establecen. Es el caso de las normas del párrafo $3^{\circ}$ del Título I del Libro II del Código Procesal Penal en cuanto en la etapa de investigación permite la entrada y registro en lugares cerrados con autorización de juez competente contenida en una orden formal, en horas determinadas, dejándose constancia escrita y circunstanciada de lo actuado por el ente investigador, obligando a la custodia y sello de los objetos y documentos que se incauten, con entrega de recibo detallado al propietario o encargado del lugar. ...Asi las cosas, las piezas signadas con las letras C. y D. del fundamento tercero, en cuanto sirvieron a los jueces de medios probatorios para dar por acreditado en autos la comisión del delito de almacenamiento malicioso de material pornográfico infantil como también la participación de autor del mismo del recurrente (considerando undécimo), en circunstancias que debieron ser excluidas por haberse obtenido con inobservancia de garantías fundamentales, como lo declara el articulo 276 en su inciso $3^{\circ}$ del Código Procesal Penal, transformándola en prueba ilícita. En este caso, y en otro sentido, al negar los sentenciadores lugar a la incidencia que al respecto promovió en el juicio oral la defensa (fundamento decimosexto), infringieron también el principio del debido proceso contemplado en el inciso $5^{\circ}$ del $N^{o} 3$ del artículo 19 de la Constitución Política de la República, ya que al permitir la incorporación y ponderación de prueba ilícita en el proceso lo despojaron de legitimidad" (el paréntesis es propio) ${ }^{59}$.

Refiriéndose luego a la doctrina de los frutos del árbol envenenado y al alcance de sus efectos respecto de la restante prueba allegada al proceso penal, el fallo agrega a continuación:

"SEXTO. Que el recurso en esta parte mira más allá aún. Partiendo de la base de la ilicitud de la prueba inicial, siguiendo la doctrina de los "frutos del árbol envenenado" acuñada por los fallos de los tribunales Norteamericanos, pretende que se le dé el mismo trato a la prueba obtenida posteriormente por la policía investigadora del delito que hasta ahora se ha hecho caudal. Sin embargo, estos sentenciadores no concuerdan en ello. En efecto, como ya se ha dejado establecido, el resto de los elementos probatorios fueron logrados cuando el hecho ya se habia válidamente judicializado, cuando se encontrada controlada la actividad policial por un Juez de Garantía competente, y obrando además premunidos de las órdenes e instrumentos legales correspondientes. En tal caso no se divisa la derivación directa de este actuar con la anterior, por ende, no puede ser esta una razón más para considerar conculcadas garantías constitucionales y legales del imputado".

59 SCS, de 11 de junio de 2007, Rol No 1. 836-2007. 
En otros términos, el fallo citado reitera aquí la tesis sustentada por el TC español en su sentencia 81/1998, de 2 de abril, antes comentada, en el sentido de incorporar como requisito del examen de exclusión la necesaria relación de antijuridicidad a que dicha sentencia se refería, y no simplemente la relación de causalidad a que apuntaba su anterior doctrina.

Por otra parte, y en lo que concierne a la oportunidad procesal idónea para excluir la prueba de fuente ilícita, la CS ha aclarado también que junto con la facultad que el art. 276 CPP le confiere al Juez de Garantía en la audiencia de preparación de Juicio Oral, debe considerarse también la facultad de los jueces del juicio oral para ponderar la prueba y, por ende, para excluir la obtenida con infracción de garantías fundamentales:

15. - Que, asi las cosas, la pretensión del recurrente en cuanto se ha vulnerado a su respecto la garantía del debido proceso como consecuencia de la "exclusión de su prueba" por ilícita, amén de ser equivoca, ya que el tribunal luego de recibirla durante el curso de la audiencia, la valoró en la etapa procesal correspondiente y conforme a los razonamientos que se consignan en el mismo, procedió a restarle mérito o valor probatorio, situación que como se dijo, satisface las exigencias de fundamentación del fallo y no puede ser considerada como lo pretende el recurrente, un acto de exclusión de la misma, correspondiendo por el contrario y precisamente, a aquel proceso intelectual razonado y lógico, que conforme con las disposiciones legales aplicables, han hecho los sentenciadores, sin que la distinta apreciación del órgano persecutor, pueda significar o importar la configuración del vicio que sirve de sustento al recurso intentado por esta causal"60.

Por último, y siempre en relación con la prueba ilícita en el proceso penal es menester mencionar también la norma contenida en el artículo 9 del Código Procesal Penal, que señala:

Articulo $9^{\circ}$. - Autorización judicial previa. Toda actuación del procedimiento que privare al imputado o a un tercero del ejercicio de los derechos que la Constitución asegura, o lo restringiere o perturbare, requerirá de autorización judicial previa.

En consecuencia, cuando una diligencia de investigación pudiere producir alguno de tales efectos, el fiscal deberá solicitar previamente autorización al juez de garantía.

Tratándose de casos urgentes, en que la inmediata autorización u orden judicial sea indispensable para el éxito de la diligencia, podrá ser solicitada y otorgada por cualquier medio idóneo al efecto, tales como teléfono, fax, correo electrónico u otro, sin perjuicio de la constancia posterior, en el registro correspondiente. No obstante lo anterior, en caso de una detención se deberá entregar por el funcionario policial que la practique una constancia de aquella, con indicación del tribunal que la expidió, del delito que le sirve de fundamento y de la hora en que se emitió".

${ }^{60}$ SCS, de 20 de septiembre de 2006, Rol No 3. 570. 
En consecuencia, por una parte el artículo 276 ya citado proscribe la prueba ilícita y faculta al juez de garantía para excluirla en la audiencia de preparación del juicio oral; y por la otra el artículo 9 faculta al mismo juez de garantía para autorizar diligencias de investigación que pudieren llegar a privar al imputado -o a un tercero- de un derecho garantizado constitucionalmente. No existe sin embargo conflicto alguno entre ambas normas pues tal autorización judicial, como lo ha entendido también la doctrina y la jurisprudencia en España en punto a la aplicación amplia del artículo 11.1. de la LOPJ, amén de encontrarse debidamente motivada, debe tener necesario sustento en una previa habilitación legal. En otros términos, tan ilícita es en estos casos la prueba obtenida e incorporada al proceso directamente, sin intervención del tribunal; como aquella que lo ha sido previa autorización del juez, pero sin norma legal previa que lo habilite para concederla. Como señala Gimeno, tomando como base para ello la jurisprudencia del Tribunal Europeo de Derechos Humanos, "la prueba ilícita es predicable de cualquier prueba obtenida con infracción de derecho fundamentales, sea quien sea el autor de la vulneración, y sea quien sea el que aporte la prueba al proceso", a lo que debe añadirse que "no es posible restricción alguna de derechos fundamentales en el curso del proceso, ni aún con intervención o autorización judicial y respecto al principio de proporcionalidad, si no existe una previa habilitación legal o autorización del legislador al efecto" 61 .

\subsection{La prueba ilícita en la Ley $N^{\circ} 19.968$ (D. O. de 25/8/2004):}

Al igual que en el proceso penal, la Ley $\mathrm{N}^{\circ} 19.968$, que crea los Juzgados de Familia en Chile, consagra como regla general el principio de libertad probatoria y de medios de prueba.

El artículo 28 de la ley señala en este sentido:

"Artículo 28. - Libertad de prueba. Todos los hechos que resulten pertinentes para la adecuada resolución del conflicto familiar sometido al conocimiento del juez podrán ser probados por cualquier medio producido en conformidad a la ley".

A su vez, el artículo 54 permite la incorporación al proceso de todo medio apto para generar el convencimiento del juzgador, en los términos siguientes:

"Artículo 54. - Medios de prueba no regulados expresamente. Podrán admitirse como pruebas: peliculas cinematográficas, fotografias, fonografías, video grabaciones y otros sistemas de reproducción de la imagen o del sonido, versiones taquigráficas $y$, en general, cualquier medio apto para producir fe".

Sin embargo, junto con consagrar la libertad de prueba y de medios la ley incorpora también una importante innovación en esta materia, lo que demuestra nuevamente

${ }^{61}$ Gimeno Sendra (2005) pp. 136 y 137. 
la clara preeminencia que en nuestro ordenamiento positivo se confiere al respeto y tutela de los derechos fundamentales en la tarea de producción de la prueba.

En efecto, el artículo 31 de la ley mencionada, refiriéndose al contenido de la Audiencia de preparatoria, dispone:

"Artículo 31. - Exclusión de prueba. El juez de familia, luego de estudiar la admisibilidad de las pruebas ofrecidas, de resolver las convenciones probatorias y de escuchar a las partes que hubieren comparecido a la audiencia preparatoria, ordenará fundadamente que se excluyan de ser rendidas en el juicio aquellas que fueren manifiestamente impertinentes, tuvieren por objeto acreditar hechos públicos y notorios, resulten sobreabundantes o hayan sido obtenidas con infracción de garantías fundamentales. Las demás serán admitidas y se ordenará su rendición en la audiencia de juicio respectiva".

Echamos en menos, sin embargo, una mayor regulación del procedimiento a seguir para establecer en el proceso la ilicitud de la fuente de la prueba, de manera de evitar que ella sea producida en la audiencia de juicio (suspendiéndola incluso en casos necesarios). La norma citada contempla, como único trámite previo a resolver sobre la exclusión de la prueba ilícita, la necesidad de oír a las partes en la Audiencia de preparación. Nada dice, sin embargo, sobre la necesidad de ofrecer a su vez prueba sobre la fuente de aquella que se considera ilícita, de la forma de rendirla en el juicio, ni de los efectos que una solicitud de exclusión debidamente fundada genera en el proceso.

A falta de normas específicas que resuelvan el problema, consideramos aplicable en estos casos lo dispuesto en el artículo 61, que regula las materias que deben tratarse en la Audiencia referida y, en concreto, lo prescrito en sus numerales $7^{\circ}$ y $9^{\circ}$. El primero de ellos, pues, contempla de modo general la necesidad de fijar en esa audiencia "los hechos que deben ser probados", mientras que el segundo ordena "recibir la prueba que sea posible rendir en ese momento", por lo que el juez deberá someter a discusión y prueba la cuestión de exclusión en la misma audiencia, fijando los hechos a probar y recibiendo la que se presentare en ese momento. Si la rendición de esa prueba genera a su turno controversia en punto a su veracidad, autenticidad o integridad, será aplicable lo dispuesto en el artículo 336 del Código Procesal Penal, al que se remite el artículo 62 inciso final de la Ley $\mathrm{N}^{\circ} 19.968$.

Por último, advirtamos en esta parte -aunque con alcance general a todo cuanto hemos dicho antes- que así como a la parte afectada le asiste el derecho al rechazo de la prueba de fuente ilícita, así también debe reconocérsele como contrapartida a aquella que la aporta el derecho a que la decisión de inadmisión se encuentre debida y razonablemente fundamentada. La regla general, reiteremos, es la libertad de prueba y de medios, por lo que la exclusión de alguno de ellos no puede nunca asentarse en criterios arbitrarios. Así lo ha dicho reiteradamente en España el TC, cuyos razonamientos son aquí plenamente aplicables. Así por ejemplo, en su sentencia 89/1985, de 19 de julio, expresa que "el derecho a las pruebas solo se satisface cuando las pruebas propuestas se acogen o si se deniegan, justificando al mismo tiempo el juicio de pertinencia que exige 
el art. 24 CE". Asimismo, en la sentencia $N^{\circ}$ 50/1988, de 22 de marzo, citada por Sanchis Crespo ${ }^{62}$, el mismo tribunal declaró que "así como la parte debe alegar y fundamentar la trascendencia y relevancia de la prueba o que esto resulte de los hechos y peticiones de la demanda, también debe el juez o tribunal explicitar su juicio negativo a la admisión de la prueba”.

\subsection{Prueba ilícita en el Código de Procedimiento Civil:}

A diferencia de lo que ocurre con el Código Procesal Penal y en la Ley $N^{\circ} 19.968$, el Código de Procedimiento Civil chileno - CPC- no contiene norma alguna que se refiera a la exclusión de la prueba de fuente ilícita, lo que podría favorecer alguna interpretación amplia que reconozca la posibilidad de introducir toda clase de prueba al proceso, bastando el cumplimiento formal de las normas que regulan los medios de prueba y sin importar, sin embargo, el origen ilegítimo de su fuente. Del mismo modo, no existe en el CPC norma alguna que permita aplicar supletoriamente determinadas normas del CPP, como ocurre -a la inversa- con el artículo 52 de este último cuerpo legal; o como lo previno por su parte el artículo 62 inciso final de la Ley $\mathrm{N}^{\circ} 19.968$, ya citado.

A lo anterior debemos añadir, además, que el artículo 346 inciso final del CPC niega el recurso de apelación en contra de aquellas resoluciones que disponen la práctica de alguna diligencia probatoria, con lo que podría reforzarse a primera vista una tesis como la apuntada más arriba, en cuanto a la admisibilidad de toda prueba esencial y pertinente, cualquiera que sea su fuente y sin derecho a reclamo alguno de la parte afectada.

Sin embargo, y conforme se ha fundamentado en los párrafos precedentes, una interpretación como la apuntada carece de sustento y debe ser desechada; máxime si la legislación procesal penal y de Juzgados de Familia lo hacen hoy de manera expresa. La ausencia de normas procedimentales en materia civil, como las recientemente introducidas en la LEC española según se dijo en el acápite precedente, no autoriza en modo alguno a obviar todo el catálogo fundamental y garantista que la Constitución Política consagra y asegura, al momento de obtener la fuente de prueba.

Como lo señala expresamente el artículo 6 de la Carta Política, los órganos del Estado -y entre ellos los tribunales de justicia- deben someter su acción a la Constitución y a las normas dictadas conforme a ella, agregando a continuación que tales preceptos "obligan tanto a los titulares o integrantes de dichos órganos como a toda persona, institución o grupo", concluyendo por último que su infracción "generará las responsabilidades y sanciones que determine la ley".

Del mismo modo, y según se dijo antes, el artículo $19 \mathrm{~N}^{\circ} 3$ de la Constitución Política de 1980 consagra el derecho a un proceso "legalmente tramitado", racional y justo, lo que implica por cierto el cumplimiento y respeto de los derechos fundamentales de las partes, durante todo su desarrollo. Un proceso civil que termine en una sentencia basada en prueba ilícita, obtenida con infracción de derechos fundamentales, no puede considerarse como "legal", y menos "racional y justo". 
Por lo anterior, entonces, en el proceso civil el juez no solo tendrá que admitir, recibir y ponderar la prueba proporcionada por las partes; antes que eso y si así se acredita en el juicio por vía incidental, estará además obligado a rechazar y considerar como nula toda aquella que se haya obtenido con infracción de derechos fundamentales. Más aún, deberá rechazar incluso su práctica misma, de manera de evitar toda posible contaminación o injerencia de esa prueba ilícita en el proceso de formación del convencimiento jurisdiccional respecto el fondo de la cuestión controvertida.

Consideramos necesaria sin embargo la pronta consagración y regulación explícita de este instituto en la legislación procesal civil, como ha ocurrido ya, según vimos, en el procedimiento penal y de familia. En este sentido, el actual anteproyecto de Código Procesal Civil ${ }^{63}$, preparado por el Departamento de Derecho Procesal de la Facultad de Derecho de la Universidad de Chile y entregado recientemente al Ministerio de Justicia para su estudio, representa un esfuerzo mancomunado que sin duda debe aplaudirse, pues, en lo que aquí concierne, constituye sin duda un avance desde que se reconoce explícitamente la exclusión de la prueba de fuente ilícita en el proceso civil (artículo $267 \mathrm{~N}^{\circ} 7$ y artículo 282 del anteproyecto, respectivamente). Sin embargo, sus normas -que son muy similares en este aspecto a las que se contienen en la Ley $\mathrm{N}^{\circ}$ 19.968, ya citadas-, presentan el mismo vacío que apuntábamos antes, en el sentido de no contener regulación alguna sobre la oportunidad en que se debe plantear y la forma en que se debe tramitar el reclamo de exclusión, como sí lo hace en la LEC española el artículo 287 y que, como sabemos, faculta además al juez para proceder de oficio en estos casos. Esperamos por lo mismo que en su proceso de revisión y estudio se salven las omisiones indicadas, de manera de prevenir las dificultades que sin duda surgirán en caso contrario. No parece necesario ni conveniente, en fin, repetir el error de limitarse a consagrar legalmente la exclusión de la prueba de fuente ilícita como sanción en el proceso civil, sin complementar al mismo tiempo tal declaración con un vehículo procesal que sirva de cause idóneo para arribar a la decisión jurisdiccional que habrá de excluir $-\mathrm{o}$ no- la prueba de fuente cuestionada. Fue esta precisamente la situación por la que debió transitar ya el ordenamiento jurídico español, desde la dictación del art. 11.1 LOPJ ya mencionado (en el año 1985) hasta la regulación del procedimiento contemplado en el art. 287 LEC (en el año 2000) para permitir la efectiva aplicación de la norma precitada.

Por último, hemos visto cómo en España, antes incluso de incorporarse en su ordenamiento positivo los artículos 11.1 de la LOPJ y 287 de la LEC, respectivamente, el problema de la prueba de fuente ilícita ya había sido abordado y resuelto por el TC, a través del recurso de amparo contemplado en el artículo $53 \mathrm{~N}^{\circ} 2$, en relación con el artículo 161.1 b), de la Constitución española de 1978. En Chile, por su parte, el artículo 20 de la Carta Política concede el recurso o acción de protección constitucional para ante la Corte de Apelaciones respectiva, ante toda privación, perturbación o amenaza de la garantía constitucional del artículo $19 \mathrm{~N}^{\circ} 3$ inciso $5^{\circ}$, entre otras, proveniente de un acto u omisión ilegal y arbitrario. Por lo anterior, nos parece que encontrándose la

63 UNIVERSIDAD DE CHILE (S/D). 
controversia respectiva sometida ya al conocimiento de un tribunal ordinario, en el marco de un proceso civil legalmente incoado, resulta innecesario e injustificado el recurso a esta vía de protección constitucional. Así lo ha dicho reiteradamente por lo demás la jurisprudencia de los tribunales superiores de justicia en Chile.

Sin embargo, distinta será la situación si el tribunal ante el que se hace valer la prueba de fuente ilícita se niega, sin fundamento ni razón alguna, a revisar y controlar su origen. En tales casos, reiteramos, si el juez admite prueba derivada de la infracción de derechos fundamentales no puede hablarse ya de un "debido proceso" ni de uno "justo y racional", por lo que bien podría intentarse esta vía constitucional en el entendido que la protección de tales derechos, como lo señala el artículo 6 de la Constitución Política, obliga a todos los órganos estatales y a los miembros que los componen.

\section{CONCLUSIONES}

1. Tanto el ordenamiento constitucional español como el chileno reconocen lo que en doctrina se ha denominado "el derecho a la prueba". Sin embargo, el Estado de Derecho impone la aplicación proporcional y armónica de los diversos derechos fundamentales que la Constitución asegura a las personas, por lo que en caso de conflicto entre la obtención de la verdad y el respeto de los derechos fundamentales en el tránsito de la actividad probatoria, deberá darse preeminencia a estos últimos y restarle todo valor a las fuentes obtenidas con infracción de los mismos.

2. En el ordenamiento jurídico español se han incorporado dos normas -arts. 11.1 LOPJ y 287 LEC-, originados sin duda en la labor jurisprudencial que en materia de obtención ilícita de la fuente de prueba ha realizado el Tribunal Constitucional.

Lo anterior, sin embargo, ha sido posible a la luz del art. 24 de la Constitución española, que consagra el derecho a la tutela judicial efectiva, el derecho a un proceso con todas las garantías y a que no se produzca indefensión. La referida Carta Magna, en efecto, faculta el acceso directo de los justiciables ante el Tribunal Constitucional a través del recurso de amparo (art. 53.2 CE y arts. 41 y ss. LOTC), lo que ha permitido corregir situaciones como la obtención ilícita de la fuente de prueba.

En Chile, en cambio, no existen mecanismos jurisdiccionales que permitan a las partes recurrir directamente ante el Tribunal Constitucional ante la violación de derechos fundamentales, encontrándose reservado el conocimiento de tales asuntos, vía acción o recurso de protección constitucional (art. 20 de la Constitución Política de 1980), a los tribunales ordinarios (Cortes de Apelaciones en primera instancia y Corte Suprema en sede de apelación).

Por otra parte, el recurso de inaplicabilidad por inconstitucionalidad contemplado en el artículo $93 \mathrm{~N}^{\circ} 6$ de la Carta Política, del que sí conoce el Tribunal Constitucional, no resulta idóneo para reclamar contra la obtención ilícita de la fuente de la prueba, pues su finalidad consiste exclusivamente en la declaración de inaplicabilidad de una ley vigente en una cuestión pendiente ante un tribunal ordinario o especial.

En consecuencia, en Chile la vía para solicitar el amparo de los derechos constitucionales es eminentemente ordinaria, por lo que una vez que se llega a la última instan- 
cia de dicha jurisdicción no resulta posible acceder al Tribunal Constitucional, como ocurre en España.

3. El Tribunal Constitucional español, en la STC 81/1998 de 2 de abril, sobre la obtención lícita de una fuente de prueba que a su vez deriva, sin embargo, de otra que se obtuvo ilícitamente (doctrina del fruto del árbol envenenado), ha dado un paso atrás en la protección de los derechos fundamentales de los ciudadanos, rebajando las exigencias para que no se consideren lesionados los derechos fundamentales en el proceso de adquisición de fuentes de prueba.

4. En el Derecho chileno las nuevas normativas (Código Procesal Penal y Ley $\mathrm{N}^{\circ}$ 19.968) han reconocido explícitamente la trascendencia de la cuestión bajo análisis, optando en cada caso por la supremacía y el respeto de los derechos fundamentales antes que por la obtención a ultranza de la pretendida verdad en el seno del proceso. No resulta posible aplicar supletoriamente, con todo, las normas sobre prueba ilícita del $\mathrm{CPP}$, al no existir una norma que así lo permita (como ocurre a la inversa con el artículo 52 CPP). A la inversa en cambio, en España el art. 287 de la LEC podría ser aplicado supletoriamente por los tribunales en los procesos penales, por aplicación del art. $4^{\circ}$ de la misma ley.

Queda pendiente en Chile la reforma de la legislación procesal civil en esta materia, con la debida regulación del cauce procedimental que echamos en menos sin embargo en el Anteproyecto en actual estudio.

5. Lo anterior no implica que en Chile los jueces y magistrados no deban velar actualmente por el mismo respeto de los derechos fundamentales en la tarea de obtención de las fuentes probatorias, en aplicación directa de las normas constitucionales que así lo ordenan.

6. El Anteproyecto de Código Procesal Civil en Chile constituye en este sentido un esfuerzo y avance valioso, aunque presenta vacíos en su regulación que deberán salvarse en su proceso de estudio.

\section{BIBLIOGRAFÍA CONSULTADA}

Carocca Pérez, Alex (2003): Manual De Derecho Procesal (Santiago, LexisNexis).

Díaz CABILE, José Antonio y MARTÍn MORALES, Ricardo (2001): La garantía constitucional de la inadmisión de la prueba (Madrid, Civitas) 245 pp.

EsPARZA LEIBAR, Iñaki (1995): El principio del debido proceso (Barcelona, Ed. Bosch) $258 \mathrm{pp}$.

Fidalgo Gallardo, Carlos (2003): Las pruebas ilegales: de la exclusionary rule estadounidense al artículo 11.1 LOPJ (Madrid, Centro de Estudios Políticos y Constitucionales) $525 \mathrm{pp}$.

GARberí Llobregat, José y ButTrón RAMíreZ, Guadalupe (2004): La prueba civil: doctrina, jurisprudencia y formularios sobre prueba, procedimiento probatorio y medios de prueba en la nueva Ley de Enjuiciamiento Civil (Valencia, Ed. Tirant lo Blanch) 600 pp.

Gimeno Sendra, Vicente (2005): Proceso Civil Práctico (Madrid, Ed. La Ley) vol. IV. 


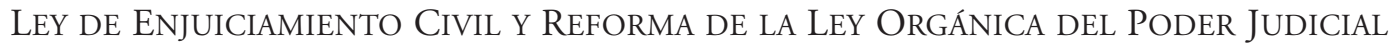
(1998): Informes a los Anteproyectos (Madrid, Consejo General del Poder Judicial).

Ley Orgánica del Poder Judicial (1986): Trabajos Parlamentarios (Madrid, Ed. Secretaría General de las Cortes Generales).

MARTíneZ García, Elena (2005): "La evolución de la doctrina de 'los frutos del árbol envenenado' en la jurisprudencia del Tribunal Constitucional”, en: VV. AA., Presente y futuro de la Constitución Española de 1978 (Valencia, Tirant lo Blanch) pp. 501-514.

Montero ArocA, Juan (1998): La prueba en el proceso civil (Madrid, Tirant lo Blanch) 326 pp.

Universidad de Chile (S/D): “Anteproyecto Código Procesal Civil” Disponible en http:// www.minjusticia.cl/Anteproyecto\%20CoProCivil/Anteproyecto\%20Codigo\%20Procesal \%20Civil. pdf, [fecha de consulta: 15 de marzo de 2006].

PIno Reyes, Octavio (S/D): "La exclusión de la Prueba ilícita", Revista Procesal Pena $\mathrm{N}^{\circ} 17$.

Ríos FueYo, Sebastián (S/D): "La Protección Civil del Derecho a la Intimidad", Revista Procesal Penal.

SANCHIS CRESPO, Carolina (1999): La prueba por soportes informáticos (Valencia, Tirant lo Blanch) $174 \mathrm{pp}$. 